INTERNATIONAL MONETARY FUND

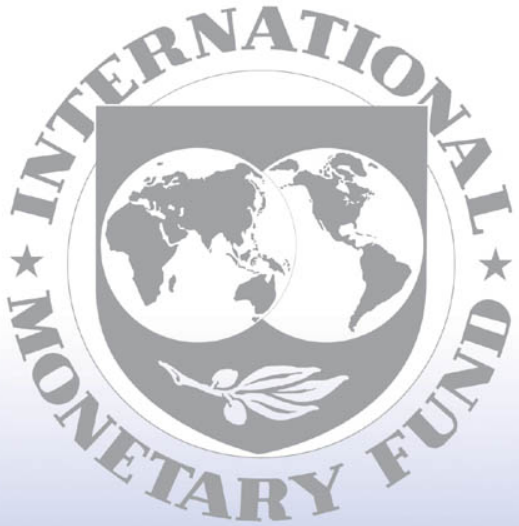

Staff

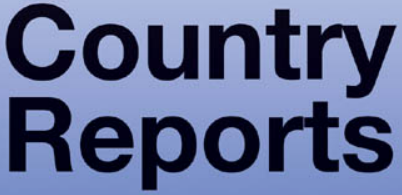




\section{Georgia: Poverty Reduction Strategy Paper Progress Report}

Poverty Reduction Strategy Papers (PRSPs) are prepared by member countries in broad consultation with stakeholders and development partners, including the staffs of the World Bank and the IMF. Updated every three years with annual progress reports, they describe the country's macroeconomic, structural, and social policies in support of growth and poverty reduction, as well as associated external financing needs and major sources of financing. This country document for Georgia, dated January 2005, is being made available on the IMF website by agreement with the member country as a service to users of the IMF website.

To assist the IMF in evaluating the publication policy, reader comments are invited and may be sent by e-mail to publicationpolicy@imf.org.

Copies of this report are available to the public from

International Monetary Fund • Publication Services

$70019^{\text {th }}$ Street, N.W. • Washington, D.C. 20431

Telephone: (202) 623-7430 • Telefax: (202) 623-7201

E-mail: publications@imf.org •Internet: http://www.imf.org

Price: $\$ 15.00$ a copy

\section{International Monetary Fund Washington, D.C.}


This page intentionally left blank 


\section{Progress Report}

\section{Economic Development and Poverty Reduction Program}

Tbilisi, January 2005 


\section{List of Contents:}

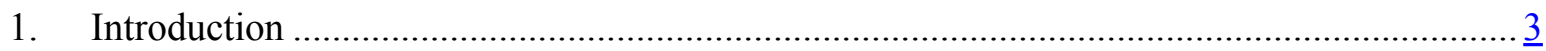

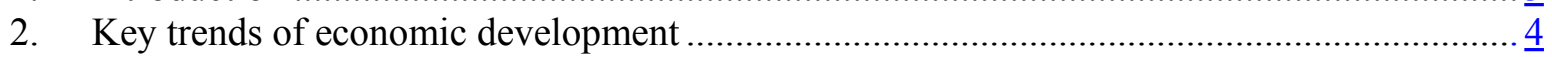

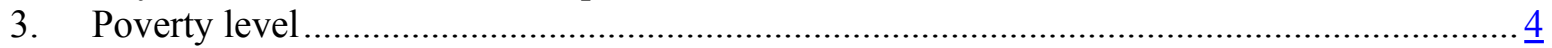

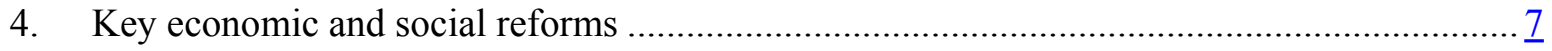

4.1. Improvement of governance and fight against corruption ............................................ $\frac{8}{2}$

4.2. Pulling private capital and improving the business climate ………………………….... $\frac{9}{2}$

4.3. Privatization ...............................................................................................

4.4. The reform of the social assistance system (monetization) ………………………….....

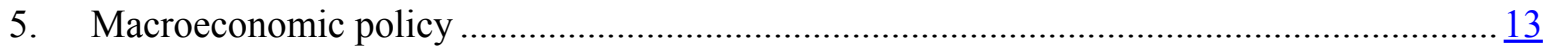

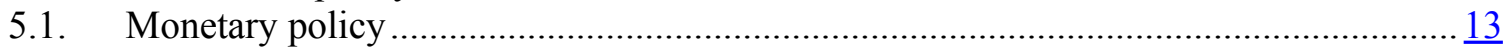

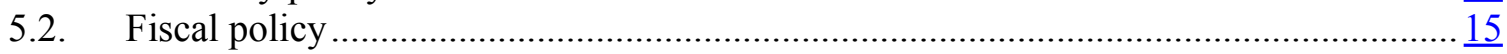

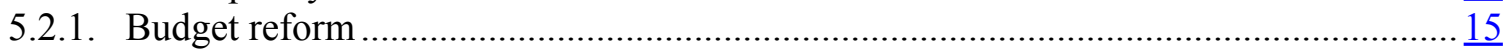

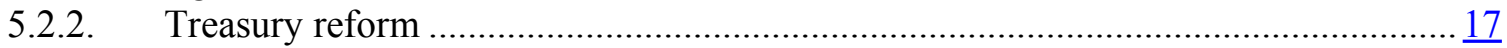

6. Current and planned reforms in sectors .................................................................. $\frac{18}{18}$

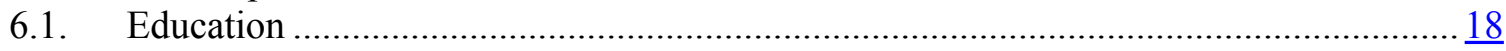

6.2. Healthcare and social security …………………….......................................

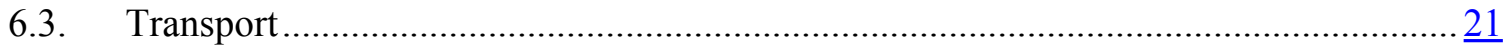

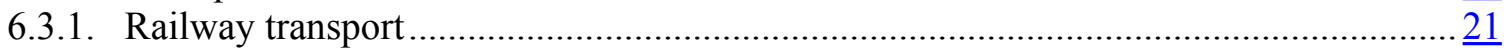

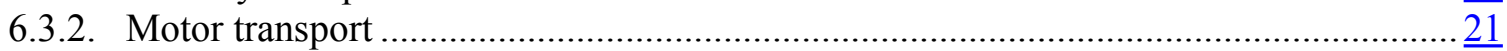

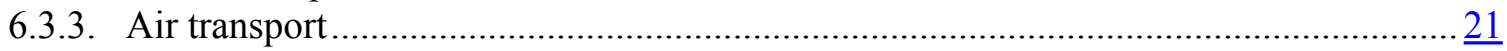

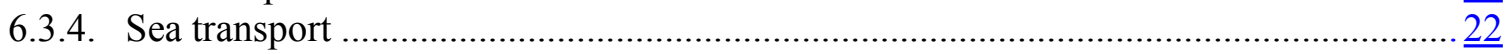

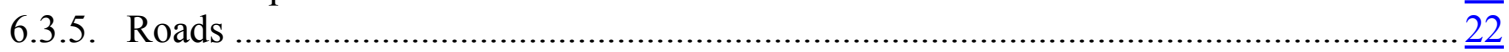

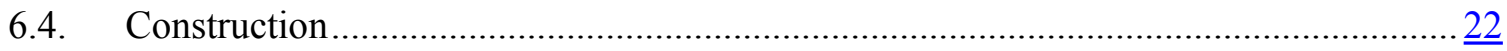

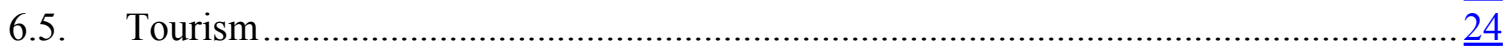

6.6. Environmental protection ..........................................................................

6.7. Development of agriculture …………………………………………………... $\frac{27}{29}$

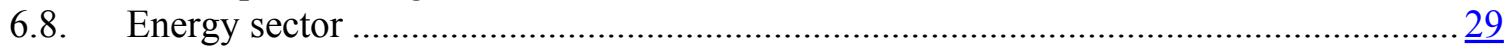

6.9. Reforms in the Ministry of Justice.....................................................................

7. Social and economic rehabilitation of post conflict zones ................................................

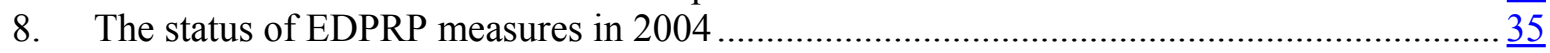

9. The consistency of the draft state budget 2005 with EDPRP measures .................................. $\frac{36}{36}$

10. Medium Term Expenditure Framework (MTEF) ........................................................

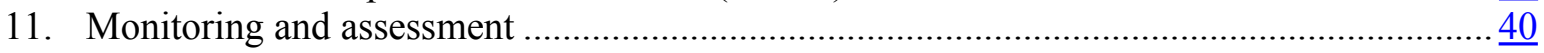

12. Annexes 


\section{Introduction}

The Economic Development and Poverty Reduction Program (EDPRP) has been developed in close consultation with the civil society, international organizations and donor countries. The EDPRP was discussed and approved in June 2003, and the government of Georgia subscribed to its implementation. The EDPRP is a comprehensive and a long-term strategy paper, which needs to be discussed on regular basis in view of adapting it to current developments in the country.

As a result of central political changes in November 2003, the rule of the old regime came to its end. After persuasive victory in the 2004 January elections the New President and the New Government came to power. They brought a new reform vision and a new strategy for statehood building; to ensure coherent implementation of the state reform program, a number of inter-related key principles were identified as priorities. The key priorities are:

- Eradication of corruption;

- Enhancement of transparency and public monitoring;

- Reduction of size of bureaucracy and its influence;

- Increase of public participation in decision making processes;

- Enhancement of professional qualifications of public servants;

- Ensuring the supremacy of the law and equality of all before the law;

- Protection of human rights;

By setting up these principles the government of Georgia takes over a moral responsibility to base its reforms on the justice and equality principles. The stated principles are in full correspondence with the key principles of the EDPRP that have been acknowledged by the Cabinet of Ministers. Thought, the reforms and the development strategy designed by the new government prompted the need for reconsideration of the three-year action plan envisaged by the EDPRP.

The acceptance of the EDPRP principles and priorities by the new government was reflected in strategy documents developed following the "Rose Revolution". The government plan of 2004-2009 alongside the statement of the government of Georgia at the donor conference in Brussels in June 2004 once again demonstrated the readiness of the government to target the national development policy on overcoming poverty and achieving sustainable and rapid economic growth.

Both documents that have been mentioned above emphasize that there is a need for effective implementation of the reforms envisaged by the EDPRP to decrease abound social inequality, which is a result of poverty. The government of Georgia understands that the poverty eradication is a necessary precondition for restoration of the country's unity and its establishment as a modern European state.

The government has also committed to making a substantial contribution to achieving millennium development goals. The Draft Report on Millennium Development Goals for Georgia developed in cooperation with civil society representatives and UN agencies in Georgia proved the need for a comprehensive and targeted policy to ensure the alleviation of extreme poverty and the establishment of adequate social-economic conditions for the population of Georgia.

It is important that the first goal of the Millennium Development Declaration of the UN - reduction by half the proportion of people who live below the poverty line - fully coincides with the goal of the EDPRP, in particular: reduction of extreme poverty level from $15 \%$ to $4-5 \%$ and reduction of poverty level ratio to the official living wage from $52 \%$ to $20-25 \%$ by 2015 . According to the basic report, the government will have to put serious effort and implement a coherent policy to achieve the outlined goals. The government's policy shall be focused on the most effective utilization of the results of the economic growth . 
Considering the afore-mentioned the government of Georgia, observing the participation principle, intends to prepare the next three year EDPRP action plan, which will fit in the mid term expenditure framework and lay grounds for result oriented implementation of the reform.

The present EDPRP progress report has been prepared on materials submitted by line ministries and government agencies. An intergovernmental working group that included representatives from ministries, government agencies and independent experts was set up to prepare the draft. The Ministry of Economic Development coordinates the process.

\section{Key trends of economic development}

Based on the preliminary data of the State Department of Statistics, GDP in Georgia amounted to lari 9800.0 million (5148.8 million US\$) in 2004, i.e. GDP per capita of approximately Lari 2160.8 (1135.3 US\$). Real GDP growth was 8.4 percent. The sustainability of high economic growth is a positive tendency in the economy of Georgia. The key contributors to high GDP growth were traditionally sectors such as industry, construction, transport and communication. Negative growth was observed in agriculture.

The central driver of economic growth was the Baku-Supsa-Ceyhan (BTC) pipeline construction. The project had a positive impact on the development of construction and service sectors in Georgia. The BTC project also allowed for the employment of many people, which substantially increased the income of the population and pushed the demand on the domestic market.

As a result of measures implemented by the government to improve tax obedience, the demand on the national currency increased in Georgia, which led to the appreciation of lari nominal exchange rate. The National Bank of Georgia successfully used monetary instruments at hand and through regulating broad money it maintained price and exchange rate stability. The fiscal situation significantly improved in 2004. For first the time ever in past years, actual revenue collections exceeded planned levels by 14 percent in Q1-04, whilst actual budget expenditures were 26 percent high than in the previous year. The spending was directed mainly on public administration, social security and debt servicing. The share of salary payments in total spending was noticeably high, which reflected the reform-oriented efforts of the government in managing human resource of the public sector.

\section{Poverty level}

Demographic and social conditions radically changed in Georgia in the past decade. The size of the population, following a trend observed in past years also, was decreasing in the reporting period though with less intensity than in the 90s. As a result of negative natural and mechanic developments in the population (dropping birth rates, intense external migration, high share of reproductive age people among migrants and etc) the ageing of the population increased.

External migration still remains a key factor leading to a dropping rate of the population. Migration is mostly prompted by economic reasons. The social and economic hardship in the country, the shortage of highly paid jobs and a less favorable entrepreneurial environment forces people to search for a living outside Georgia. Their remittances are one of the most important sources of household incomes. Migration vis-à-vis poverty in short-term perspective is more of a result than a cause, however if maintained at such levels, it could become one of the reasons for deteriorating conditions in the country. The latter might lead to such adverse developments as dropping share of economically active population, which strains the labor force balance, increases social-demographic pressures on the employed strata of the population alongside the number of dependents on them (above and under economically active age).

According to the SDS data, in 2003 poverty level was 54.5 percent to subsistence level and increased by 2.4 percent points against 2002, which can be considered a substantial increase. The increase in the poverty level was contributed by high rural poverty (increased by $7.7 \%$ ) though urban poverty decreased by 2.7 percent. 
The level of poverty reduced to 52.3 percent in the first 9 months, however we estimate the change to be seasonal The growth of rural poverty took an irreversible pace in the past period, which may be clearly observed in the dynamics of extreme poverty. Extreme poverty made 17.4 percent in the first 9 months of 2004 which is 0.8 percent high than in 2003. The dynamics of extreme urban poverty demonstrates that urban poverty, unlike rural, is not linear, nor uni-dimentional, and is reducing.

Table 1. Official and extreme poverty levels in 1996-2003 and 9 months of 2004 (urban and rural)

\begin{tabular}{|l|l|l|l|}
\hline \multicolumn{2}{|l|}{} & Urban & \multicolumn{2}{l|}{ Rural } \\
\hline Official poverty level & \multicolumn{2}{l|}{ Average } \\
\hline $\mathbf{1 9 9 6}$ & 56.4 & 46.7 & 52.1 \\
\hline $\mathbf{1 9 9 7}$ & 46.9 & 45.4 & 46.2 \\
\hline $\mathbf{1 9 9 8}$ & 54.4 & 45.3 & 50.2 \\
\hline $\mathbf{1 9 9 9}$ & 60.5 & 41.8 & 51.8 \\
\hline $\mathbf{2 0 0 0}$ & 57.0 & 46.1 & 51.8 \\
\hline $\mathbf{2 0 0 1}$ & 54.4 & 47.6 & 51.1 \\
\hline $\mathbf{2 0 0 2}$ & 55.4 & 48.5 & 52.1 \\
\hline $\mathbf{2 0 0 3}$ & 52.7 & 56.2 & 54.5 \\
\hline $\mathbf{2 0 0 4}$ & 51.3 & 53.4 & 52.3 \\
\hline Extreme poverty level & & & \\
\hline $\mathbf{1 9 9 6}$ & 16.8 & 10.4 & 14.0 \\
\hline $\mathbf{1 9 9 7}$ & 10.5 & 9.2 & 9.9 \\
\hline $\mathbf{1 9 9 8}$ & 16.2 & 11.1 & 13.8 \\
\hline $\mathbf{1 9 9 9}$ & 18.1 & 11.8 & 15.2 \\
\hline $\mathbf{2 0 0 0}$ & 14.4 & 14.1 & 14.3 \\
\hline $\mathbf{2 0 0 1}$ & 14.2 & 13.4 & 13.8 \\
\hline $\mathbf{2 0 0 2}$ & 15.3 & 15.0 & 15.1 \\
\hline $\mathbf{2 0 0 3}$ & 15.2 & 18.0 & 16.6 \\
\hline $\mathbf{2 0 0 4}$ & 15.0 & 19.8 & 17.4 \\
\hline
\end{tabular}

Source: Department of Statistics, the Ministry of Economic Development

As for poverty indicators according to regions, poverty is high in Kvemo Kartli were 78 percent (3/4) of the population lives under the poverty line and $1 / 3$ in extreme poverty.

The level of poverty is lower in Kakheti and Adjara, where 68.5 percent and 64.7 percent of households live under the official poverty line. The level of poverty is the lowest in Tbilisi and Imereti, where 44.5 percent and 39.6 percent of the population live under the official poverty line. In summary, the poverty level by regions is not uniform.

According to 9 months' period data, the average monthly income of one household made lari 300.2, which is 6.6 percent high than last year, but if we take into consideration developments in consumer prices, than real incomes have decreased. The average monthly expenditures of households increased by 8.4 percent in the reporting period and made lari 356.2, though increased by 0.8 percent in real terms. The share of groceries in household expenditures is 60 percent which is 3 -times high than in developed countries.

The GINI index made 0.35 in 2003 per capita, which means it practically did not change since the comparable period in 2002.

The GINI index was 0.48 by total incomes, which also remained unchanged compared to the previous year. The GINI index by incomes, as usual, is high than by consumption. Using both distributions, the GINI index follows downward trend. 
Graph No. 1: Change in the GINI index

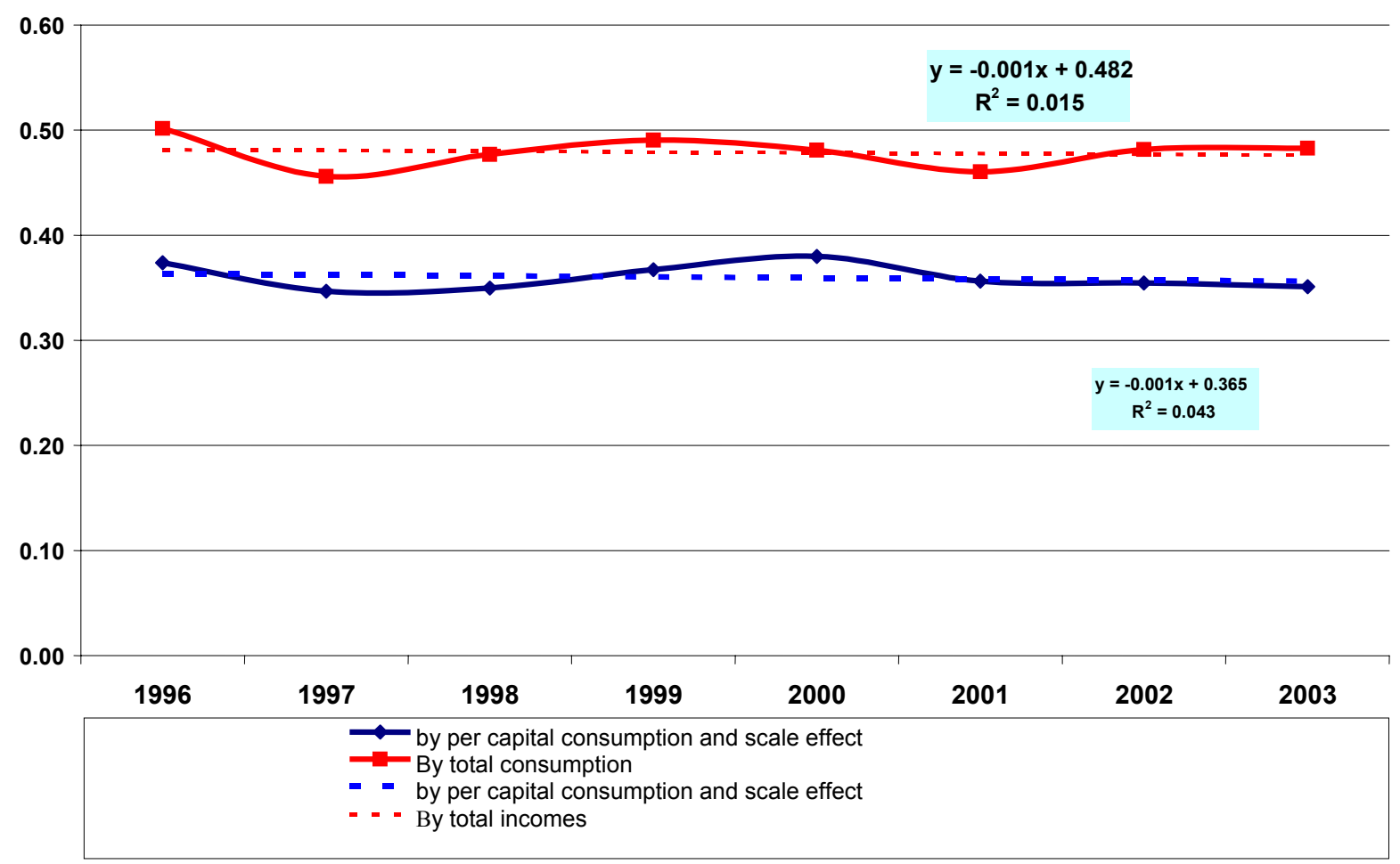

Source: the Ministry of Economic Development

The GINI index substantially differs by regions: per capita consumption Shida Kartli 0.29 and Kakheti 0.36 .

The difference in GINI index between regions is more vivid by total incomes. The highest inequality is observed in Tbilisi and Adjara where GINI index is 0.53 and 0.51 respectively, though the difference between Guria and Samegrelo is less: 0.41 and 0.43 respectively. The inequality level has increased in Samegrelo in comparison to past years. As a rule, the GINI index in Samegrelo region was relatively lower than in other regions, and the tendency has been maintained in 2003 also, but if we reckon a slight decrease in average national index, then rising inequality in Samegrelo is observable.

The GINI index per capita consumption is identical in rural and urban levels and makes 0.35. Pursuant to the household survey, GINI index follows a downward tendency at urban level, and an upward trend at rural level, which points to rising inequality due to increasing poverty levels in rural areas. The latter points to distressing hardship and an irreversible deterioration of conditions in rural areas. 
Graph No. 2: GINI index per capita and the scale of effect in rural and urban areas

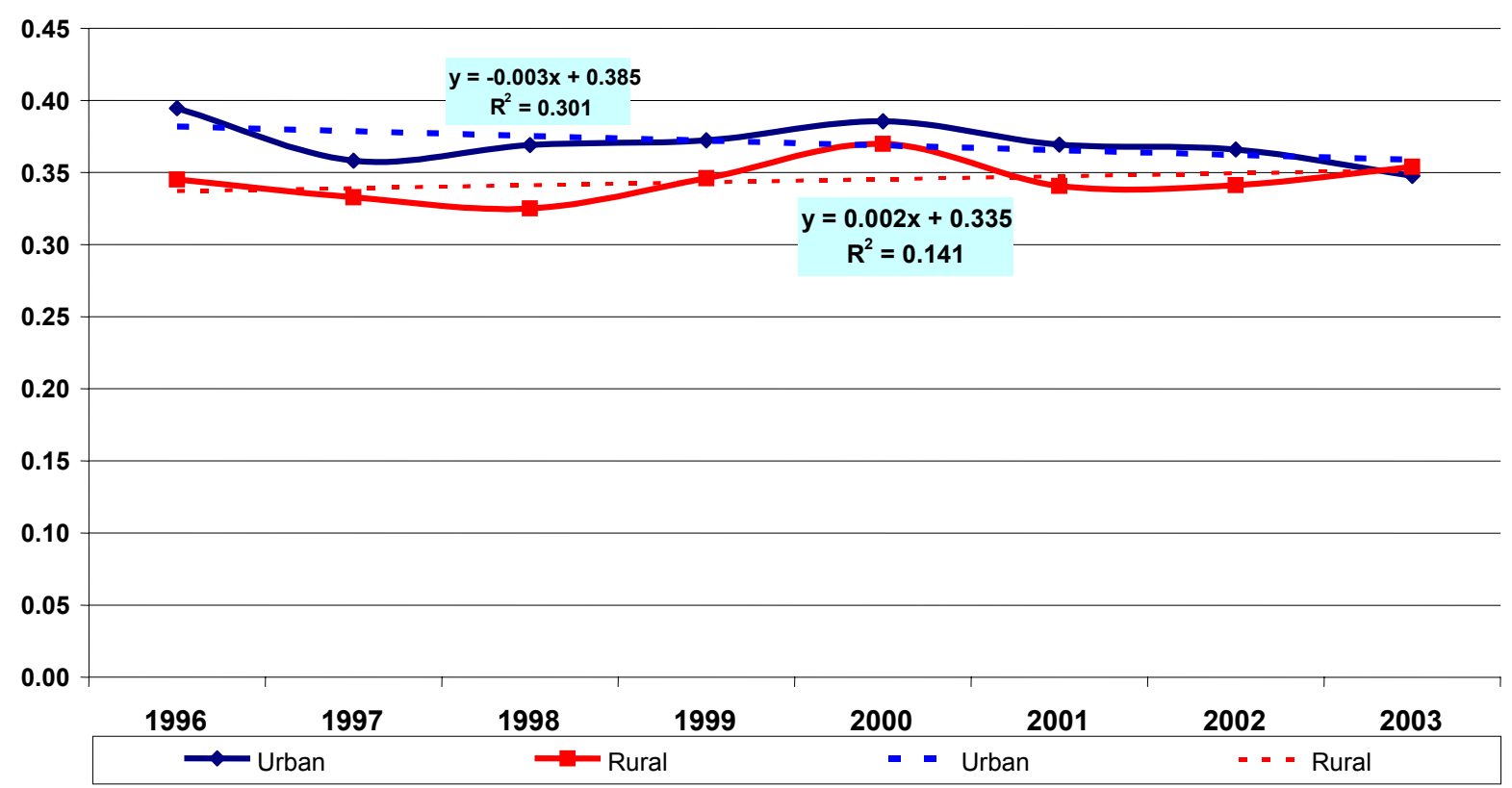

Source: the Ministry of Economic Development

Among other factors, unemployment is the main cause of poverty. The unemployment rate by ILO definition was 12.7 percent in the first 9 months, and 15.2 percent by soft definition, which represents an increase. The lion share of unemployment comes on structural unemployment. Low salaries of contractual employment also contribute to the poverty level. Average monthly salary of a contractual employee made lari 120, which is 89.2 percent of the subsistence level in the corresponding period. When describing households, their assets are most central for assessing their food security. Households that are void of assets have a 56 percent more probability of facing shortage of food than households that possess assets. The share of households that experience hunger and shortage of nutrition is rather high. It should be noted that food shortage will have an affect on their individual demographic, economic and social behavior in nearest years.

In view of the afore-motioned, in order to overcome poverty it is advised to: 1) increase assets of the poor, 2) the assets of the poor and the sector they represent should grow at a high pace and 3) given time is needed to harvest tangible results of this strategy the protection and expansion of consumption by poor households requires public transfers in a short term perspective.

\section{Key economic and social reforms}

The approach of the government towards economic and social reforms implies alleviating current poverty by a surged and sustainable economic growth. The improvement of governance mechanisms by enhancing their transparency and efficiency, the improvement of business climate and pulling private capital through the implementation of a series of liberal economic reforms is imperative to the promotion of economic growth. In order to make the reforms and the process of their implementation more effective, an apparatus of the State Minister for Coordination of Economic Reforms was created. 


\subsection{Improvement of governance and fight against corruption}

One of the key tasks of the government of Georgia is to fight corruption wide spread in different areas and implement governance related reforms. The strategic aim of the authorities is to establish an efficient, professional, decent and transparent civil sector, which will serve for the protection of democratic principles. The latter may be achieved through executing anti-corruption measures centering on reforming law enforcing and judicial systems, as well as fiscal, administrative and public services. With a view of effectively implementing these reforms, an appropriate legislative base shall be developed. Serious steps have been taken forward to enhance the efficiency of law enforcing structures. In particular, as a result of the road police reform a Patrol Police was created, which also assumed the public order defense function. Closure of the road police control stations facilitated to eradication of corruption. To strengthen fight with economic and financial crime, a Financial Police was created under the Ministry of Finance. To optimize the law enforcement agencies in the country the Ministry of Security and the Ministry of Internal Affairs have been merged. As a result, the Ministry of Police and Public Order was created.

The anti-corruption measures assumed in the past period have led to the improvement of the fiscal administration.

To ensure the coordination and committed implementation of governance reforms, a Civil Service Council and a Civil Service Bureau (to provide support to the latter) were set up pursuant to the President's Decree. The key responsibility of these bodies is to promote the creation of a public service that will meet modern demands and will determine the success of current and planned public reforms.

Some initial measures have already been assumed in reforming the system of governance. The number of ministries was downsized from 18 to 13 through mergers. 18 state departments were abolished and brought under the subordination of corresponding ministries as sub-agency institutions, which will substantially enhance their efficiency. The cabinet of ministers guided by a team spirit has been set up under the leadership of the Prime Minister. In each ministry reforms are underway aimed at abolishing units with duplicate responsibilities, redistributing competencies and downsizing the personnel. These processes are not uniformly successful which one again points to the necessity of coordination. With a view of providing a legal complement to these adjustments, the Parliament of Georgia introduced important amendments to the Law on Public Service as well as approved some important bills. The Law of Georgia on the Structure and Rules of Activity of the Executive Authorities of Georgia was replaced with the Law on the Structure, Competencies and Rules of Activity of the Government of Georgia. The legislation on public services will further be improved in future.

The next challenging step of the public service reform is to staff government agencies with appropriate human resources. The efficient performance of the civil service calls for the appointment of resources with relevant qualification and competence. To secure the afore-mentioned, competitive selection shall be administered, public servants will be tested on periodic basis, training will be offered, a reserve list of resources shall be drawn and etc. These measures will ensure the selection, appointment and constant training of resources that match job requirements as closely as possible.

At present there are several education institutions in Georgia that carry out the preparation and training of public servants. However, a single public system that could have uniform principles and approaches, education programs and standards is not present. Currently each organization manages these processes at discretion. There was an attempt from the State Chancellery to establish order in this area. A concept was developed to prepare and train public servants, corresponding normative acts were issued, a center of public administration, preparation and training of public servants was established, which produced several analytical, methodical and educational materials, but the proposed measures failed to be implemented. At present proposals (to be implemented in the nearest future) have been developed to resolve the afore-mentioned problem. 
Successively adequate organizational culture must be cultivated in Georgian public agencies. The latter requires the fulfillment of complex work or the key component of organizational culture - the code of ethics for public servants.

There is no uniform system for compensating labor in public service at the current stage. The benefits employees at different public agencies are entitled to are not comparable, which negatively affects motivation and efficiency. Specific proposals have been developed to establish a single compensation policy and regulate the compensation system in the public sector. The proposals are being discussed at the government level and both minimal wages and public sector salaries will substantially increase from next year, which will progressively continue in upcoming years. The salary increase must first of all promote the competitiveness of the public sector vis-à-vis the private sector.

A high step to improve the governance system is the development of e- governance, which is a labor intense and time-consuming process.

\subsection{Pulling private capital and improving the business climate}

Development of industry, attraction of investments, implementation of anticorruption reforms and legalization of shadow economy are among the key priorities of the Country.

The crucial measure among the government's efforts to pull private capital and improve the business climate is the adoption of the new Tax Code, which has been developed by close consultations with NGOs, business circles and independent experts. EDPRP had also envisaged substantial reform and refreshment of the tax system of the country to align it with the country's realities. The new Tax Code has been approved by the parliament of Georgia and entered into force on January 1, 2005. The tax reform aims to improve the business climate, establish favorable conditions for both local and foreign investors, simplify tax procedures and legalize the shadow economy. On the whole, the reform serves for the promotion of economic growth based on liberal principles.

The new Tax Code lowers tax rates and simplifies the tax system across-the-board. It envisages 7 taxes instead of 21, namely: social, profit, property, income, VAT, excise, and gambling tax. The reduction of tax rates is also planned, namely social tax $20 \%$ (instead of 33\%), VAT $18 \%$ (instead of 20\%), income tax $12 \%$ (establishes a proportional system with a single rate to replace the quasi-progressive system of 4 rates on cumulative incomes). These changes bring two positive effects on the tax payer: 1) lower taxes and more cash resources at disposal (net income in this case) and 2) a simplified mechanism for calculating taxes. A $100 \%$ amortization principle is adopted, which means that a person may register acquisition of fixed assets as expenditures during the same year as they had been acquired and deduct them from the taxable profits. This will allow the company to pay less profits tax while investing in fixed assets or not pay at all for the next few years. This innovation will help the investment process.

Concessional conditions are envisaged for some categories defined by the "National Classificator of Economic Activities", in particular for the self-employed, which represent a sizeable share of the population (1.2 million out of 1.8 million pp). According to the new Tax Code, entrepreneur physical persons, who do not employ other labor are exempt from income and social tax. (Profits tax is not applied to entrepreneur physical persons). If VAT taxable turnover of a taxpayer does not exceed 10000 lari annually, he is also exempt from VAT.

Given the majority of the employment focuses on the agricultural sector, the new Tax Code envisaged special concessions, namely agricultural land plots under 5 hectares that has been in private ownership as of March 1, 2004 shall be exempt from land tax. Property tax is not imposed on to-be-cultivated agricultural land for 5 years from the day of its allocation/titling. Supply of raw agricultural produce is also exempt from VAT. Up to 100000 lari income of an individual entrepreneur, who does not employ other labor, and who supplies/trades processed agricultural produce is exempt from income and social tax. 
Also, non-entrepreneurial, immovable property of a household, whose income does not exceed 40000 lari annually is exempt from property tax with regard to this immovable property.

The new Tax Code focuses on a series of institutional adjustments in the tax sphere, of which the alternative dispute resolution option at the private arbitrage, next to the court is one of the key initiatives. The function of this legal instrument is to support rapid dispute settlement on taxes. The role of the courts in the tax administration process increases. Another institutional novelty is the introduction of the tax ombudsman post, whose duties shall be to protect the rights of taxpayers.

The government of Georgia embarked on an unprecedented decision to eradicate the high scale of shadow economy and the practice of tax evasion, namely the financial and property amnesty initiative. The government developed a draft law on legalizing property and undeclared tax liabilities, which aims at supporting the establishment of a legally and economically liberal environment and targets at full engagement of the civil capital in economic processes.

The key priorities of the draft law are:

- No controlling and law enforcing body shall be allowed to check economic activities (transactions) carried out before January 1, 2004;

- No one shall be authorized to check the source of the declared property, including financial assets

- Citizens shall be given a deadline from the day the law is enacted to end-2005 to submit property and financial declarations, which will provide an opportunity to legalize declared assets.

- A moratorium on property inspection shall be declared in 2005

- The property information submitted by the taxpayer shall be kept confidential

- With a view of legalizing his/her financial status, a citizen shall be liable to make a one time payment of 1 percent.

Among the EDPRP measures aimed at promotion of industry and investments, eradication of barriers to business is one of the key, reduction of number of controlling agencies, ensuring transparency in the process of granting licenses and rights are parts of the initiative.

At present, the volume of shadow economy is extended due to the problems characteristic to the process of obtaining licenses and rights, as well as due to multiplicity of controlling and regulating agencies in the country, and their ineffective functioning. Nowadays 30 state agencies issue 65 different licenses and rights. This creates a barrier to entry; there is no reason for requiring license for many business activities that need to be licensed at present; some agencies issuing some of the licenses are market players themselves. Legal content of licenses and rights is mixed. When there is a regulation in the country where interests of the regulators and other market players coincide, consumer rights are not protected, and freedom of an action and development of a supplier is restricted, the regulation fee becomes a type of a tax and violates market conditions; it becomes impossible to improve business climate and create healthy investment environment in the country.

Considering all the abovementioned, the Government of Georgia intends to deregulate the economy of the country, which mainly means simplification of the fee and licenses system, optimization of controlling agencies and institutional reform of tariff regulations.

The ultimate goal for the institutional regulation is eradication of barriers to economic development. Market players shall be given a possibility to develop in a free environment. According to the planned reform, the tariffs will be regulated only in electricity, gas, water and telephone communication services. While all other spheres where tariffs that are being regulated by tariffs at present will not be regulated any more. It is imperative to note that the new regulation rules envisage regulation of only the ceiling tariff, while the market players (producers, distributors, suppliers and consumers) will have a possibility to coordinate the size of a tariff. By applying this principle, the price derivation process will be conducted in real market terms and will protect the consumers interests. 
In terms of the reform, the deregulation process will be accompanied by strengthening the administrative and criminal responsibilities; every agency that has a right for tariff regulation at present will be deprived this function an Independent Multisectorial Tariff Regulating Board (IMTRB) will be created. The IMTRB will be accountable to the government regarding their activities on an annual basis. The Board will be financed from the state budget.

The main principles of the reform have been discussed at the government's session. The aims and tasks of the reform received positive assessment and at present the work is underway to draft a schedule of measures to be implemented in terms of the reform.

\subsection{Privatization}

The privatization launched in Georgia in 1993 involved small and medium scale entities (commercial, household servicing establishments, drug stores and etc) mostly. At the first stage, the key aim of the privatization was to formulate a stratum of private owners, to promote small and medium business development and by thus solve some social problems and introduce market economy principles.

Currently, the state property privatization is aimed at privatizing large scale enterprises. State-owned entities in the telecommunication, transport, industry and mining sectors are being prepared for sale.

The process of privatization was launched in the Autonomous Republic of Adjara. At the current stage mainly social infrastructure entities are being privatized (commercial sections, hotels).

The privatization of land and forestry resources shall also be carried out gradually. As of now, 74.8 percent of agricultural land and 2.5 million hectares of forests are in state ownership. A draft law on "Privatizing agricultural lands in state ownership" has been developed. The aim of the draft is to ensure that after privatization of agricultural land, the established landownership rules are market oriented, so that land is utilized in an effective and productive manner. As a result of privatization, economically profitable and agriculturally productive plots will be privately owned, thus, effectively utilized. Privatized land plots will participate in the land market, it will increase access to credits and improve investment environment. As a key result of approval of this draft, about 160 thousand hectares of land plots that are now being underutilized will be employed in agriculture; Also, privatization of the 200 thousand land plots that now are being leased will stimulate the entrepreneurs to make more capital investment in these plots and improve productivity of the land.

In the law on state budget 2004, privatization receipts of lari 81.4 million are envisaged. The Ministry of Economic Development has already mobilized lari 71.7 million as a revenue of the consolidated budget of Georgia (among them 67 million were revenues of the central budget ).

The Draft Law of Georgia on State Budget 2005 stipulates that privatization gains in central budget will make lari 94.2 million. We should take into consideration the fact that in 2005 receipts from privatization will exceed targeted parameters of the budget by about 200 million lari. The incremental revenues will be utilized to finance activities in the following sector:

- Defense - lari 80 million

- Education - lari 17 million

- Energy sector - lari 40 million

- Pension reform - lari 24 million

- Foreign debt service - lari 39 million

The government aims at implementing a fair and transparent privatization. With a view of securing a high level of fairness and transparency, the government of Georgia intensely works to establish international contacts and engage international observers in the privatization process. A dedicated web site (www.privatization.ge) has been created to provide full information on privatization in Georgia. 
The Ministry of Economic Development set up a hotline and a privatization center that offer rapid and competent advice and information to interested individuals and companies. The government of Georgia pays a close attention to the ways of utilization of the money that materializes as a result of privatization. At present, the government works intensively to design a model of effective management of the sums that are expected to become available. The work will be concluded in the near future.

Also, Work is underway to improve the normative base and develop privatization mechanisms qualitywise. Namely, the following have been prepared and adopted: regulations on privatization of state property through direct sale and competitive bidding, regulations on determining opening prices of state property, Presidential Decree No, 468, dated 26.10.04 on introducing amendments to Presidential Decree No. 671, dated 17.11.97, amendments to the Presidential Decree 334, dated 25.05.99 on the rule of transferring state owned property to local self-government (local government) bodies, the rules for managing and transferring fixed assets on the balance of enterprises where the state owns over 50 percent of shares. Regulations are currently drafted on writing off state property.

The government aims to complete the privatization process launched in September 2004 in 2 years.

\subsection{The reform of the social assistance system (monetization)}

The government of Georgia is fully aware that rapid and surged economic growth is the best way to reduce poverty. However to promote poverty alleviation, economic growth must be stabile. Besides, the implementation of only economic reforms will not bring an effective result as these reforms must be supplemented by measures aimed at improving the social status of the population.

With this in mind, the government of Georgia embarked on reforming the social assistance system. The reform is fully consistent with the key principles of social assistance programs outlined in the EDPRP. The centerpiece of the reform is to improve the social- economic status of the population through extreme poverty alleviation.

The key principle of the reform is the monetization of social assistance. Social assistance will no longer be oriented on certain categories of the population (e.g. invalids, war veterans, IDPs). Social assistance will give relief to all households living below the extreme poverty line. They will be entitled to a monthly cash benefit in replacement of advantages envisaged by the current legislation. Recipients will be able to use cash benefit at discretion. Cash benefits for households below the poverty line shall be determined in accordance to the current income level and size of the family.

The new system of social assistance requires a specific identification method for extremely poor households who will be beneficiaries of this assistance. Namely, key factors have to be highlighted that exert substantial impact on the economic status of a households and the weight of the factor must be determined. Subsequently, the validity of each factor for the household will be measured and by using factor weights the poverty risk of the household will be assessed. The indicator used for measuring the poverty risk must be a combined figure to synthesize various known methods in the world for assessing the economic status of households.

As of today the following has been completed:

- Based on the analysis of the household survey data of the SDS, key factors have been determined in high correlation with household consumption.

- A regression analysis was done for identified factors and a draft working formula was developed to estimate household consumption.

- Analysis was done on the selection of beneficiaries identified based on the estimates of real consumption by households and the estimates derived by using the formula.

- Poverty factors identified by current household surveys were replenished with new factors identified through empirical surveys (in-depth interviews, interviewing focus group and experts).

- The questionnaire that we have at hand and has been developed by searching additional factors, will be filled by households applying for assistance. 
To determine the final statistical indicator, those households must be interviewed (using the developed questionnaire), for whom the SDS already has poverty estimates where a four fold budget analysis was conducted. Knowing the incomes and expenditures of the household, through correlation and regression analysis it is possible to identify key factors determining the economic status of the population and the impact of these factors on the economic status of households. In other words, we should come up with a formula to assess the economic status of each household that submits an application in the framework of the social assistance program.

As for the non-statistical indicator, it will include those factors the spread of which is small and thus may not be reflected in the formula due to insufficient frequency. However, these factors exert much importance on the economic status of the household. The following groups are at high poverty risk: orphans, single aged people, families with many children, people with no families and etc. Each factor will have a weight proceeding from additional needs each category has by norm. Through statistical and non-statistical (combined) indicators households will be ranked by poverty risk. The ranked row will allow us to determine a risk group. The economic status of the household in this risk group will be finalized by a social worker and only then final decision will be rendered on awarding social assistance.

A this stage a special working group has been set up composed of government officials and NGO representatives that will develop identification strategy and method by end Q1-05 and by end of April 2005 will identify, develop and adopt a final version of the questionnaire (application) and weights of indicators. The new social assistance system will be presented in Q4-05.

\section{Macroeconomic policy}

\subsection{Monetary policy}

The main priority of the National Bank of Georgia (NBG) is to conduct the monetary and exchange rate policy oriented on price stability - low and forecasted dynamics of inflation rate that is prerequisite for steady economic growth and poverty reduction in Georgia. Against a background of the decreasing of shadow economy's level and limited smuggling that had to serve as a real reason for price increase, the inflation rate was remained moderate due to monetary tools. That was supported by the Lari appreciation process. Lari appreciated by 15 percent from the beginning of year and the average exchange rate in 2004 made lari 1.92/US\$1. As a result, the price stability was remained and inflation rate was not only preserved at $5.7 \%$, but the inflationary expectations was minimized. The volume of international reserves increased approximately 2 times during the reporting period and hit a level of US\$382.8 million (from 1.3 to 2.3 in months of imports of goods and services).

One of the key priorities of the NBG is to curb the level of dollarization in the country. It is difficult to conduct the monetary policy under high dollarization scale as it limits the NBG's role of being the lender of the last resort and weakens the scope of the NBG to form interest rates. As a result of the NBG's targeted policy and the legalization of the economy, the level of deposit dollarization fell from 86.1 percent to 74.3 percent on the expense of the rising number of current accounts in national currency. It is presumed that this tendency will be maintained in succeeding years.

Since September 2003 the Rule on Calculating and Adhering to Minimum Reserve Requirements entered into force, which enabled commercial banks to deposit part of their reserve requirements on correspondent accounts as minimum averaged reserves.

The NBG reduced the reserve requirements several times in 2004 and now commercial banks have been released from compulsory reserve requirements on funds attracted in national currency, whereas the minimum averaged reserve requirement for averaged funds attracted in national currency is determined at 2 percent of such funds. These measures will free additional assets in the banking system, will make the pulling of lari deposits cheaper and will encourage commercial banks to increase the share of transactions with assets and liabilities in the national currency. 
If resources in the national currency become cheaper this will lead to a decreasing interest rate margin. The latter is a precondition to economic growth and high incomes of the population.

The NBG set into action a series of monetary instruments to promote the reduction of interest rates and attraction of deposits in national currency. Since spring 2003 overnight deposits and intraday credits were introduced and daily TICEX auctions were held, which aimed at strengthening the NBG's role as a lender of the last resort and at increasing its influence over the formation of interest rates. As a result interest rates on credit resources have lowered in the current year, which must encourage investments and consecutively be a driver for economic growth.

The NBG was challenged by the need of sterilization following positive tendencies in 2004, capital inflows from overseas and a rapid growth of reserves following the de-dollarization. With a view of solving the problem and precluding inflation, the NBG would resort to sterilization as needed with its peak reached in end October when lari 70 million was extracted from circulation. Taking into account the expected privatization gains, the NBG will keep a close eye on liquidity sterilization in future as well.

In 2004 the number of commercial banks decreased to 22 as a result of the monetary policy conducted by the NBG. The policy focused on banking sector consolidation and transparency, increasing the capitalization of banking institutions and intensifying intermediary functions. It also concentrated on establishment of specific financial markets and the promotion of trust towards the banking system.

In 2005 and in the interim period, the priorities of the monetary and foreign exchange policy shall be oriented towards the following goals:

- The key aim of the monetary and foreign exchange policy is to achieve and sustain price stability. According to the plan of the National Bank of Georgia in the medium term period (2005-2007) targeted annual inflation rate will be sustained at 5-6\%;

- For the purposes of facilitating the remonitization of economy in the low inflationary environment the NBG will supply money according to the demand for money, taking into account the real growth rate of the economy and the targeted inflation rate. The NBG is aware that demand for money will be accompanied by restriction of dollarization. On the background of legalization of economy, utilization of lari, as the only legal tender will increase. The legalization tendency will be sustained in short as well as in mid-term period. This will necessitate increase of monetary base at a significantly faster pace than GDP, not to provoke increase in prices. The draft 2005 Basic Directions Document for Financial and Monetary Policy envisages increase of reserve money by $18-20 \%$; besides, in a mid-term period, next to broadening its the payment function, the national currency will gradually acquire a saving function. This will be provoked by the monetary environment that will be created in the country. Ultimately, number of the deposits denominated in lari will increase as well as the credits issues in lari terms. This will ensure re-dollarization of the financial intermediation. On the other hand it will facilitate to increase of money multiplicator in the banking sector and enhance effectiveness of monetary transmission mechanism. The described process will facilitate to sustaining the long term trend of remonetization of the economy. For broad money M2 (broad money excluding foreign currency deposits) and M3 (broad money including foreign currency deposits) the process of remonetization will be sustained, so that remonetization indicator increases by $0.5-1 \%$ on average annually. The effectiveness of the banking system and enhancement of its intermediary function acquires a special importance in this process, to ensure that the broad money increase happens by attraction of cash that is being circulated outside the bank channels next to increase of reserve money and by improving the quality of banking services. We should take into account that remonetization of the economy shall be subordinate to the key principles of the financial/monetary policy and if any discrepancy between these two occurs, priority shall be given to the price stability as the key goal; 
- Reserve money will increase mainly due to accumulation of foreign reserves at the accounts of the NBG. Main source for the inflow of foreign reserves is financial assistance received from the international organizations and donor countries as well as purchase of foreign exchange by the NBG at the foreign exchange market;

- While selecting the instruments for the non-inflatory supply of money, the economy's significantly increased demand for money as well as the necessity of sterilization of the excess interventions (in case of excess supply of money) will be considered. So, while regulating the money supply in medium term period, the credits to the banks will be extended based on the open market operations more extensively then it has been done in previous years;

- In 2005, the foreign exchange policy shall still be based on a floating exchange rate regime. The exchange rate will be formed based on market principles, considering demand and supply for foreign exchange. In order to circumvent abrupt variations of lari due to seasonal and conjunctive reasons the NBG will apply two-side monetary interventions.

- Considering that the price stability is the ultimate goal, the NBG, within its competence will try to facilitate to the competitiveness of the exporting sectors of the country. Thus, the NBG will aim to creation of such a dynamics of a real effective exchange rate that will facilitate to creation of healthy trade relationships with the partner countries.

- Considering the situation with the country's trade balance and the volume of external debt, the accumulation of international reserves remains the key priority of the monetary policy of the NBG. The NBG will lead its investment policy accordingly, so that by the end 2005 reserve to imports (excluding imports related with the construction of oil and gas pipeline) ratio will comprise at least 2.5 months. The process of accumulation of foreign exchange reserves will also continue during the medium term period, to ensure unimpeded service of the country's foreign liabilities. It is expected that by 2006-2007 the country's foreign exchange reserves will amount to the equivalent of the 3 months imports.

- Envisaging the developing, unsustainable economic and financial environment, in case of significant domestic or external (a sharp change in the BOP) impacts on the economy of Georgia, the monetary and exchange rate policy shall be conducted with a minimum diversion from key targets.

\subsection{Fiscal policy}

\subsubsection{Budget reform}

A substantial improvement in budget arrangement is planned as part of the budget reform. The number of budget organizations decreases and the independence of agencies and organizations in determining the policy and direction of respective activities increases.

In the framework of the EDPRP the method of budget financing has shifted to program and activity financing, which sharply improves the targeted use of public funds and increases the level of efficiency.

The incomes of legal entities of public law will no longer be included in state budget revenues and expenditures (they no longer have accounts at the State Treasury). The principles of providing budget funding to organizations from the budget has also been modified - the Ministry of Finance will assign funds in specific cases to the spending units. The spending units, in their turn, will finance the legal entity of public law under their subordination that is responsible for the implementation of the program or specific activity. To reflect the latter, the organizational structure of the state budget has changed and instead of legal entities of public law, the organizational structure now indicates the program or activity.

Work in underway to improve the budget classification, which envisages the IMF recommendation of 2001 to introduce classification and use accrual instead of cash accounting method. 
A realistic monthly projection of budget expenditures shall be developed and a medium term (3-year) planning of the budget shall be conducted.

The adoption of the Budget System Law in 2003 (to be effective from January 1, 2004) may be regarded as a progressive step. The law introduced a more detailed and optimal budget schedule and clearly outlined the competencies of budget organizations and the Ministry of Finance in developing draft budgets.

The rules and procedures of budget reporting were determined, namely during 20 days following the end of the month, the MoF prepares a report showing sources of revenues, expenditures, deficit and financing, which gives more transparency and accessibility to information on budget revenues and expenditures.

Core items were abolished under the budget and the mechanism of sequestration was modified. Namely, the provision on core items was removed from the Budget System Law which means that all expenditures of the budget are a priority on equal level. The mechanism of sequestration was replaced by developing monthly cash plans for expenditures and by a quarterly consideration of the budget in the parliament, when based on the proposal of the executive authorities the parameters of the approved budget are revised upwards or downwards.

According to the Budget System Law, the inflows of all fiscal spending units shall be reflected in the state budget, and all budget inflows shall be accumulated on a single treasury account and shall be directed to finance measures pursuant to the budget law of the year. In other words, incomes of spending units will no longer be at their disposal, which leads to the abolishment of non-tax revenues (so called special funds).

Based on the requirements set forth by the law, the MoF prepared new budget request forms.

A series of decisions were taken to ensure an uninterrupted performance of the budget process, of which rules of recording and spending donor financing (cash grants) were developed, a state register of cash grants was created in the Ministry of Finance.

In 2003-2004 the MoF prepared a classification of expenditure which was discussed and approved by the Finance and Budget Committee of the Parliament. The EU standards of public expenditure classification is the key classification when budgets of member countries are designed. One of the requirements of NATO was to illustrate the defense budget of the country by activities. The classification by activities will enable us to analyze and determine correct proportions of expenditures, to ensure an efficient distribution of resources and outline the budget strategy in a more transparent and clear way.

\section{Local budget}

As a result of November 15, 1998 local self government and local government elections, the number of local budgets exceeded 1000 units. On a local-self government level there were budgets of villages, communities, settlements and towns under the regions, whereas on a local government level there were budgets of the region and towns that were not part of regions.

The afore mentioned exposed the need of developing such a legislative base, which would substantially support the real independence of local self governments and local governments.

In September 2004, the MoF prepared and the Government of Georgia submitted to the Parliament the draft on "Budget System Law of Autonomous Republics and Other Territorial Units of Georgia".

Pursuant to provisions of the Organic Law of Georgia on Local Self-Government and Local Governments and the Law of Georgia on the Budget System Law, the draft envisages expanding and specifying the fiscal authority of representative and executive bodies of autonomous republics and local governments, and improving methods of designing and implementing budgets of autonomous republics and other territorial units of Georgia. 
These issues are not adequately reflected in the current legislation. This flaw is particularly exposed when distributing revenues and expenditures among regional budgets and budgets of villages, communities, settlements and towns under regions.

As a result, in most regions, revenue distribution ratios for local self-government units are determined not on a long-term basis but for each year, and with varying rates, thus damaging the role and importance of having long term economic norms for tax revenue distribution.

The afore-mentioned creates a strain between the local self-government and local government bodies, which finally is reflected in violating the interest of self-government budgets.

The draft law is designed to fully eradicate this flaw. It clearly and innovatively formulates the rule of developing, discussing, adopting, executing and controlling budgets of autonomous republics and other territorial units of Georgia. Namely, uniform, long-term economic norms of tax and non-tax revenue distribution and transfers to these budgets, of which adjusting transfers to local self government budgets, is determined by the law of Georgia. With such an approach, we finally regularize budget competencies for autonomous republics and local governments, which have been established while observing the principle of independence.

The new rule of designing local self government budgets, which has been outlined in the draft law submitted to the parliament, allows for the determination of the size of adjusting transfers for these budgets using a formula. It ensures a per capita adjustment of local self government budgets that have low social-economic potential to an average national indicator. In addition, the transfer will be directly given to each local self government budget pursuant to the draft law.

The submitted draft law is developed by the Ministry of Finance. MPs, members of the government, stakeholder ministries, officials of representative and executive bodies of local government and self governments as well as experts from IFIs (primarily the World Bank), the association of young economists and independent experts of self-government and representatives from other NGOs are engaged in discussions over the draft.

It is estimated that the adoption of the law will increase state budget expenditures by lari 10-12 million from 2006, the source of financing shall be presented before October 1, 2005 by adjusting transfers for all self-government budgets based on calculations done according to these units.

\subsubsection{Treasury reform}

From April 5, 2004 the Ministry of Finance kick started a central reform of the treasury by 1) establishing a single treasury account and 2) enforcing a mechanism for refunds. The treasury reform aims at improving the management of public funds through recording budget inflows and increasing the trust of taxpayers towards administering timely refunds. More than 10000 transit accounts were closed at the NBG and all budget inflows are recorded on the single treasury account. Since April 5, 2004 the reporting and recording of budget revenues and expenditures is more detailed and comprehensive compared to the form previously produced by the NBG. After the implementation of the reform, on daily basis a certain portion of revenues is accumulated on a special sub-account for refunds, which gives transparency and flexibility to tax refund process. Respective legislative amendments were developed and introduced to budget, tax and customs legislation.

Technical equipment was replenished through the technical assistance of the UNDP and the USAID. The adequate software was developed and installed by the local personnel of the treasury. A reference book of treasury codes was published and given to commercial banks and taxpayers. After conducting afore-mentioned measures, the reform was successful and it keeps on working.

From the beginning of 2004, pursuant to the Budget System Law special accounts were abolished. Consequently, the treasury closed all special accounts and consolidated revenues under the budget. Thus, commitment control was established on the entire central budget except the expenditures of 
budget organizations in the Autonomous Republic of Adjara. From April 26 the regional treasury started operating on the territory of Adjara. Previously, the financing of budget organizations on the territory of the autonomous republic was carried out by the MoF of Adjara through the planned funds transferred by the treasury from the central budget, which triggered many troubles. By setting up a regional treasury office, the execution, recording and reporting of budget expenditures improved. The regional treasury is linked to the single consolidated database. The system of commitment control was established in the Autonomous Republic, thus now covering the entire central budget.

Following this achievement, work was launched to develop similar procedures for expenditures of special state funds. Legislative amendments have been prepared and joint meetings were held with representatives of the funds. As a result, based on the order of the Minister of Finance of Georgia, the treasury started monitoring expenditures of special state funds from September 1 in accordance to the rule of commitment and spending control.

A series of reforms are expected in the upcoming three years aimed at improving the performance and operational capacity of the treasury. A single revenue and expenditure account shall be set up to grant more efficiency to the management of public funds and international accounting rules shall be introduced. Both measures are extremely important for statistical and analytical purposes.

\section{Current and planned reforms in sectors}

\subsection{Education}

The key goal of the national education policy is to establish quality education system and ensure its accessibility. The development of the draft law on High Education was very important. It declares goals of high education and outlines ways of their implementation, defines the importance of High education establishments, identifies their possible organizational-legal form, rules of creation, reorganizations, liquidation and other,.

The draft law envisaged new financial mechanisms such as: financing education on the expense of public education grants, education loans, program funding of university sciences and etc. It provides a new method of managing High education institutions, which sets apart academic from financialadministrative management. For the first time, the draft law clearly determines the basic principle of High education institutions, such as academic liberty - the ability of the faculty and students of carrying out scientific research, teaching and studying independently.

The government of Georgia acknowledges its responsibility towards orphans under state custody

and children void of parental care and recognizes the need of raising them in a family and the priorities of the UN Convention on the Rights of a Child based on which the draft law on Regulating and Supporting Processes of De-institutionalization was developed. The draft law aims at promoting raising children in families, regulating the deinstitutionalization of children under state custody, separating personnel and financial competencies in the management of these processes among central and local authorities, legal relations of public agencies and organizations in the process of deinstitutionalization, developing mechanisms for the participation of civil organizations and identifying the scope of their authority and responsibility. The draft law offers different forms of civil care over a child. Practical steps have already been taken in this direction. During the past three years, the government ensures the education of individuals in institutional establishments in professional and high education institutions. Together with the European Commission, the state pays a monthly stipend of lari 50 and covers the tuition fee in private schools.

A process of accreditation has been launched which equally affects private and public education establishments. The accreditation will equally pose standard requirements for quality education to all High education schools irrespective of their legal status. The institutional accreditation verifies the consistency of the High education establishment in terms of material and human resources with conditions set by the Ministry of Education and Science. Program accreditation must determine the 
orientation of High education program, goals, teaching methods and their consistency with local and international requirements. If program accreditation is successfully passed, then education grants will be equally accessibly for both public and private high education schools.

The new model of providing public financing for high education will establish equal opportunities and accessibility irrespective of the student's solvency. At the same time, it must be noted that the government cares for the youth experiencing hardship due to certain developments, such as pupils and high education prospective students from conflict zones. In 2004, 21 students (of which 11 Ossetians and 10 Georgians) from Tskhinvali received admission to high education institutions (both to schools were tuition is free or were fees are levied). The state pays for their tuition charges and appoints a stipend of lari 50 per month. The schools in Tskhinvali region were technically equipped. At present the ministry, with support from donor organizations, carried out a series of measures aimed at strengthening the material base of education institutions: it conducts repairs in schools for underprivileged children with "Alizei", an Italian organization; through the aid of the UNICEF delivered pastime inventory in inclusive schools; replenishes the inventory of the professional lyceum of Kobuleti with the assistance of the Swiss Agency for Development and Cooperation.

The Project Ilia Chavchavadze is very important in reorganizing the system of education. Its key goals are to develop the capacity of schools to manage administrative, financial and human resources and establish national education plans. Many of the above mentioned have already been fulfilled: a system of funding general education has been created, which envisages a priority funding of schools in villages and mountainous regions; a system of textbook rental has been developed and allows a student to pay only $1 / 4$ of the value of textbooks for the year. This system is already practiced in 56 schools of Georgia.

As for the system of improving the qualification of teachers, a program of professional development for teachers is carried out currently through the co-financing of the World Bank. The program focuses on three directions:

1. Education grants;

2. The program of teachers' professional development in schools;

3. The program of developing school networks.

Each program is implemented in all regions of Georgia, of which conflict zones and mountainous regions. In 2004, 6200 teachers were involved in the professional development program.

Work was launched to develop a concept- education for sustainable development. Important measures in this context are:

- Education for good

- Education for all

- Adult education

- Introducing information technologies into education

- Development of communications

- Ecological education

Also work is underway to establish a new concept, which envisages the creation of a comprehensive system of vocational education, the optimization of the network of professional education establishments and their substance-based and structural adjustment.

Vocational education institutions are being transformed into legal entities of public law, which expands their authority and based on the current legislation transforms them into multi-functional institutions. Vocational education institutions are being transformed into regional professional education/consulting centers, which allows for student and adult (unemployed, employed) vocational training, re-training and improvement of qualifications. Methodical materials required for vocational education standards and education programs are developed while taking into consideration the feedback of employers and the strategic planning of activities of vocational institutions on the local labor market. 


\subsection{Healthcare and social security}

The social-economic hardship of the population in the past years has noticeable deteriorated the health conditions of the population. Birth rates dropped while death rates increased, of which infant mortality, thus reducing natural population growth. In parallel to declining demographic parameters, socially hazardous diseases stood out, the cases of TB and psychic illnesses increased, the rate of vaccinepreventable diseases reached an alarming level.

The key path to improve the healthcare of the population leads to fighting poverty and caring for the healthcare of the deprived. With this in mind, the Ministry of Labor, Healthcare and Social Protection, plans to bring commitments towards the population in conformity with a realistic budget. It will clearly determine the basic package of medical care (which will then lead to its realistic execution and will abolish the illusion of "pseudo-free services) and will ensure the accessibility of medical care within the scope of availability.

With a view of planning healthcare programs realistically in 2005 , the tariffs of public medical standards and prices of treatment and diagnostic services are harmonized. A new methodology of tariff setting has been developed. By cohering tariffs of standards and estimated prices, it will be possible to come up with a realistic budget for funding public medical programs.

In parallel, public medical standards are being cohered (we imply the professional value of such standards given currently they do not rely on evidence-based medicine).

Proceeding from the peculiarity of the country, the key direction of the health policy for medical care of mothers and children is the protection of a child's rights, healthy nutrition, harmonized development, a family environment and alternative care. The following measures have been planned in 2005 by the medical service of mothers and children:

- Reconsidering and revising the basic package of medical care for mothers and children

- Improving the material-technical base of medical establishments providing care for mothers and children

- Advocating for a healthy life style

- Increasing the preventive-medical awareness of the population

- Considering each case involving the death of the mother and a selective consideration of cases of a child's death

- Supervising the healthcare of a child, identifying individuals and groups with development and growth disorders.

Measures have been planned aimed at social integration of the handicapped and recording and systemizing their individual data. The project suggests the implementation of ICF classification in Georgia. The classification has been recommended by the UN and has been adopted by many countries around the world. Such a classification will allow to gather bio-psycho-social information on the handicapped and systemize it in a single electronic database. The database might be used as a central instrument for planning, managing and efficiently assessing reasonable and targeted public policy towards the disabled.

In this sphere, a priority direction for reforms is the program supporting the social adaptation of the disabled, which includes the following components:

- Expenditures for the institutional patronage of the disabled;

- The sub-component of the rehabilitation of disabled children;

- Subsidizing land and property taxes for NGOs of the disabled (associations of blind and deaf people) and enterprises set up by them. 
The government of Georgia managed to stop the accumulation of pension arrears and started the repayment of outstanding arrears. Furthermore, a pension increase to 28 lari has been planned in the beginning of 2005. This will be the first step taken towards implementing the pension reform.

\subsection{Transport}

\subsubsection{Railway transport}

The following works are underway at the Georgian Railways to develop core infrastructure for making the country's transit potential more attractive and to develop a multifunctional corridor aiming at European integration:

- In order to attract flow of cargoes works are assumed in the framework of TRASECA; the accession to the Agreement of North-South Corridor is being considered;

- Proposals have been made to develop railway-ferry connections with Turkey and expediting the construction of Batumi-Constance ferry crossing;

- With a view of improving coordination between railways and ports, ITs and infrastructure at ports are being improved and a flexible tariff policy is being developed as planned.

In order to further improve the regulatory activities in transport and communication, LTD Georgian Railways proposed the government to create a regulatory body in the railway sector for conducting a clear public policy.

With a view of simplifying the declaration, recording, customs clearance and customs check-up of railway cargoes, works are assumed to introduce modern information technologies at border-customs check points, integrate them into a single computer network and exchange information.

Currently the first stage of the reform of Georgian Railways is in progress, which envisages reducing distances and staff downsizing. From January 2005, a USAID funded project will be launched to reorganize the Georgian Railways and help them prepare a development program.

\subsubsection{Motor transport}

Important adjustments have been assumed by the motor transport administration within the range of a single public policy on motor transport. Namely, with a view of granting more attractiveness to the transit corridor and optimizing the tariff policy, the current legislation will be fully liberalized and will envisage liberal tariffs, a shift from administration to regulation (the technological control of an administrative type shall be replaced by monitoring and supervising the system of permits) while accommodating the demands and interest of consumers in accordance to market principles.

With a view of creating a competitive environment for national carriers at international markets and expedite the integration of Georgia in the international transport system, the fees on international land carriers are brought closer to fees effective in partner countries.

In terms of developing information technologies, the office of the motor transport administration has been fully computerized and connected to local and global nets, a webpage has been set up where each user can easily receive information on both passenger and cargo carriers, as well as other issues.

\subsubsection{Air transport}

Revolutionary changes in Georgia had a significant impact over the performance of civil aviation.

Several new companies entered the air market (KLM, British Airways, Arkia and others) which lead to a high (by $7-10 \%$ ) passenger turnover under conditions of adhering to flight safety requirements and strict supervision by the aviation security.

One of the key reforms undertaken in civil aviation administration is the development of the liberalization (so called open sky) concept of the activities of civil aviation. 
The current reorganized structure of civil aviation, as well as the status and legal form of its sole regulatory body (the civil aviation administration is a legal entity of public law and an independent national regulatory body) is fully consistent with international standards as concluded by the ICAO and EKAK assessment commissions.

Important steps have been taken towards European integration of the civil aviation system and the harmonization of its legislation with European standards. The conditionality for Georgia's accession to the EKAK has been fully met.

Proceeding from new reality, the draft law on licensing civil aviation activities has undergone some improvement. A number of sub-legislative acts are being prepared to support the regularization of civil aviation safety and its activities.

\subsubsection{Sea transport}

With a view of harmonizing the legislative base and standards with European legislation, sea port rules and regulations on the composition of minimal crew for a navigation of vessels operating under the flag of Georgia were adopted. The training programs for sailors have been revised in maritime education establishments.

Policy and regulatory functions have been separated. The registration of companies engaged in maritime activities and issuance of "certificate of acknowledgment" have been more intense in 2004 . As of now 51 companies have been registered, of which 30 companies in 1999-2003 and 21 companies in 2004.

With a view of implementing the TRASECA program, tariffs for down and up-loading services in sea ports have been removed from state regulation. In order to develop the maritime sector by improving management the privatization of state maritime companies is being considered.

\subsubsection{Roads}

In 2004 the Department of Roads assumed the repairs and rehabilitation of roads of public use. Current repairs were carried out on roads of international and intrastate use of $4000 \mathrm{~km}$ of length in total, which secured the safe and uninterrupted flow of traffic on these roads.

Works assumed in 2004 have been impeded by several natural calamities that took place in the year. The flow of motor transport was operationally restored after coping with the aftermath of natural disasters. As a result traffic flow vividly improved in mountainous regions, such as: Lentekhi, Ambrolauri, Tsageri, Oni, Mestia, Dusheti, Kazbegi, Chokhatauri and etc.

Through the assistance of the World Bank a $100 \mathrm{~km}$ road and one bridge will be put into exploitation. The bridge road of $4.8 \mathrm{~km}$ in the entrance of Poti will be functional owing to the financial assistance extended by the Kuwait Fund. Presumably the $57 \mathrm{~km}$ section of Samtredia-Sajavakho-Grigoleti road will be completed in the nearest future, and in $\mathrm{H} 12005$ the $7 \mathrm{~km}$ section of Ureki-Choloki road will be rehabilitated. In 20043 taxes that formed revenues of the Road Fund have been revoked. In future, construction and current repairs of roads will be financed from the central budget.

\subsection{Construction}

To optimize the methods of preparing urban construction documents for the development of settlements on the territory of Georgia and to enhance the efficiency of their implementation, a program on the preparation of urban construction documents has been developed. Namely, pursuant to the law on State Procurement a tender was announced on the development of urban construction documents for 6 towns.

Companies that will win the tender held to develop national construction norms, rules and standards shall develop and present to the ministry 18 different normative documents that will be fully 
harmonized with European legislation. Work in this direction will also be undertaken in 2005 so that in 2009 the creation of a system of normative documents harmonized with European norms was completed.

To streamline urban construction processes on the territory of Georgia and improving the efficiency of management, a draft law of Georgia on Principles of Urban Construction and Spatial Arrangement has been developed and submitted to stakeholder agencies for consideration.

With a view of eliminating illegal construction, improving the quality of construction materials and their production as well as enforcing high accountability for entities engaged in construction operations, amendments have been developed to the Law of Georgia on State Supervision of Architectural Construction Activities.

In order to simplify the preparation of construction permits, streamline relations with entities engaged in construction operations and simplify construction licenses, the Law of Georgia on Construction Permits has been developed and approved.

To protect and regularize the use of land for construction purposes on the black sea coast line of Georgia, borders of zones of constant monitoring and strict supervision have been developed and approved.

Works on the integrated general layout of the black sea coast line has been completed.

Relevant draft amendments are being developed to optimize licensing in construction and designing, improve control over and quality of performed works by licensed entities.

The regulations of the Ministry of Economic Development envisage the creation of a legal entity of public law - a national agency of expertise and licensing of construction-designing activities, which will address key directions of construction activities and thus will coordinate activities of involved construction entities. The regulations of the agency have been prepared and the agency will be effective from 2005.

To create and streamline a normative base for the preparation of urban construction documents (harmonized with European standards), the instruction and methodology for developing title zone maps of general plans for land planning, which has been submitted for approval and consideration to stakeholder organizations has been prepared.

With a view of establishing order in urban construction when setting up settlements on the territory of Georgia, basic regulations for the use of settlement territories and regularization of settlement have been prepared and submitted for comments to regions.

A joint World Bank and Bank of Georgia project on the strategy and regularization of the water supply sector of Georgia and assessing opportunities for private sector participation has been completed.

To improve the housing conditions in the country and increase the efficiency of undertaken measures the state has developed targeted programs 1) to develop public policy of social housing and 2) to rehabilitate and manage housing in Georgia.

Negotiations are underway with the governments of Georgia and Germany to receive assistance for the rehabilitation of the water supply and sanitation system of city Batumi. A pilot project is being considered to establish condominiums in multi-apartment residential houses within the framework of the Georgian-German Land Management Project.

The implementation of following measures is advisable to improve urban management and solve residential housing problems in the country: the legislative base must be streamlined, public housing policy principles must be developed; modern mechanisms must be established for introducing housing management, a single state database on the housing fund must be created that could meet modern standards, programs must be developed targeted at dealing with the consequences of natural calamities 
and relieving the expected damage, the model of social housing must be introduced as part of a single national policy on housing in Georgia.

\subsection{Tourism}

Georgia has significant potential to develop as a tourist destination and a resort. At present tour packages that offer cultural, ecological or adventurous trips to Georgia are very competitive tourist products at international travel markets.

Currently the legislative base on tourism and resorts is being enhanced. Proposals have already been made to revoke some normative acts. Currently amendments are introduced into several legislative acts and state regulation mechanisms are been streamlined. State regulation in the sector of tourism will be oriented on encouragement (so called intense method) and not restrictions. The fulfillment of certain criteria determined by the state will be both profitable and advantageous for the private sector. At present the Department of Statistics of Georgia works to identify a methodology to measure economic effectiveness of tourism as an industry. This measurement system will be based on international standards.

Amendments were adopted by the Parliament in August 2004 to the Law of Georgia on Temporary entry, stay and exit of foreigners in Georgia. The amended law provides for simplified visa procedures and lowers visa tariffs, namely foreign visitors will be able to receive entry visas upon arrival not only in the airport, but also in every border check-point of Georgia.

The key for development of the tourism industry in Georgia is enhancement and popularization of international image of the country. To achieve this goal it is imperative to actively participate and promote Georgian tourist products at international tourist fares and exhibitions, which will ultimately result in increase of interest in the country and facilitate to creation of demand for tourist products.

In November 8-12 Georgia for the first time ever throughout its independence participated in the World Travel Market (WTM) in London. At the tourist fair the Georgian stand exhibited the state as well as private sector products. It is planned that the Georgian tourist product will be exhibited in Milan (BIT), Minich (C-B-R), Berlin (ITB), Tokyo (JATA) and London (WTM) tourist fairs. This will significantly increase interest to Georgia among professional stakeholders and potential tourists

Work is underway to develop inside the country tourism in Georgia. Special attention is given to tours to rural arrears, as well as new types of tourism such as agricultural and wine tourism in Georgia.

The planning and implementation of the program for development of the recreational zones of Georgia will be continued.

According to the SDS data, 368.3 thousand tourists visited Georgia in 2004, among them 218.5 thousand were from the CIS. The number of tourists in 2004 was $17.5 \%$ more than relevant indicator of the previous year.

\subsection{Environmental protection}

The unfavorable ecological condition of Georgia calls for the creation and operation of a new system of environmental protection and usage of natural resources, which will be part of the economic development strategy.

The key tasks of public policy in the sphere of environmental protection and usage of natural resources are:

- Integrating environmental care activities in social-economic development of the country

- Strengthening the legislative base in the environmental care sphere

- Improving ecological expertise

- Intensifying international contacts and participating in solving global ecological problems 
- Improving the quality of drinking water, surface waters and air in urban developments

- Solving problems in the management of hazardous chemical substances

- Saving the black sea from pollution

The following environmental measures are especially noteworthy within the EDPRP: the project on the development of a reserve in ecosystems of forests in the Central Caucasus, the integrated management project of the Georgian black sea coast line, open program of Borjomi-Kharagauli National Park, supporting the infrastructure of the auxiliary zone of Borjomi-Kharagauli National Park and rehabilitating entities of communal infrastructure.

\section{Developing national reserves in the forestry eco-systems of the Central Caucasus (2003-2005)}

The project goals are: 1. supporting the detailed plan of biodiversity and conservation of eco-systems in the Central Caucasus region and developing a management plan for ecological corridors in East Caucasus; 2. Developing three protected territories (Vashlovani, Lagodekhi, Tusheti) for the conservation of bio-diversity in east Georgia, which will support the generation of incomes for the local population and parks, and will encourage sustainable development of adjacent territories. The project envisages creating infrastructure for setting borders of protected territories, constructing centers for visitors and the administration, shelters for guards, check up points and facilities for managing visitors.

Eight new protected territories have been created and the existing ones have expanded. Tusheti National Park was created (83453 hectares), and the protected landscape (27903 hectares), the Vashlovani National Park (25114 hectares), Lagodekhi (1996 hectares) and Ilto (5273 hectares) enclosures, natural monuments of Alazani grove (138 hectares), Takhti-Tepa and Artsivi gorge. The territories of Vashlovani and Lagodekhi reserves have expanded (8-34 to 8489 and 17932 to 22358 hectares respectively). The protected territories created on Akhmeta reserve (Batsara, Babaneuri and Tusheti) have been separated into two administrations: Batsara-Babaneuri reserve and Ilto enclosure. The administrations of protected territories were transformed into legal entities of public law.

\section{Integrated management project of Georgian black sea coast line}

The project aims to create protected territories with a view of conserving the unique eco-system of extra humid territories of Kolkheti, protecting the habitats of its flora and fauna, generating incomes to supplement public funding and exercising scientific, education and tourist activities.

The following has been implemented in the range of the project:

- The protected territories of Kobuleti and Kolkheti have been established and the government ensures their basic funding;

- Initial aid was consolidated to encourage economic activities of the population residing adjacent to Kolkheti protected territories;

- The government of Georgia was given expert consultancy to analyze the environmental impact of oil transportation pertinent to projects to operate on the adjacent zone of the Kolkheti protected territories;

- Draft amendments for the harmonization of the legislative base of Kolkheti protected territories has been developed in consultation with the local population and the management

Currently the project is concerned with protecting the unique eco-systems of Kolkheti extra humid territories and in preventing its biodiversity from degradation.

The project also aims at providing assistance to the poor and vulnerable population of the adjacent zone to Kolkheti National Park, namely:

- Identifying and resorting to alternative sources of income

- Improving rural infrastructure

- Supporting fishing and the production of agriculture goods

- Preserving the natural functions of Kolkheti valley 
Within the framework of the project, community organizations of 30 villages that reside in the adjacent zone to Kolkheti National Park will receive small grants to promote the rehabilitation of socialeconomic infrastructure, to encourage of alternative sources of income and preserve central natural functions of Kolkheti valley.

\section{Open Program - Borjomi-Kharagauli National Park (2003-2004)}

The program aims at: creating the infrastructure of Borjomi-Kharagauli National Park, managing pastures of the park, developing the adjacent zone and Borjomi-Kharagauli National Park itself. Current works within the range of the project have been completed as of today.

\section{Supporting the infrastructure of Borjomi-Kharagauli National Park adjacent zone and rehabilitating entities of communal infrastructure}

The project aims at: creating a communal union for water supply, sanitation and cleaning and support its further development. The following works have been completed:

- In 6 regions construction projects have been prepared for the rehabilitation of water supply and works are underway pursuant to the projects.

- Water company employees are being trained within the framework of the project;

- New methods of management are introduced in the planned union.

The important measures implemented in 2003 in terms of the UN "Clean Development Mechanism" (CDM) for the purposes of changing the climate are also noteworthy. These measures are closely related with the economic development of the country.

- In November 2003, a memorandum of understanding was signed between the Ministry of Environment and Natural Resources of Georgia and The Ministry of Environment Protection of Denmark for reduction of gas emissions from the hotbeds in the framework of CDM.

- In terms of the abovementioned agreement the project proposals were received for collection of methane emitted to the atmosphere from Lilo dump and further utilization of the methane; identification of investments for Tbilisi gas supply pipes reconstruction in return to the decreased supply of methane, rehabilitation of the major gas pipes,implementation of production line for the new types of pesticides/ carbamide, that will reduce emissions of carbonic acid and azot;

- In January 2003 an authorized national body was created that would ensure implementation of the provisions of CDM.

- In 2004, a technical assistance project by TACIS was commenced that intended to train an expert for the authorized national body and adopt a national procedure for approval of the CDM projects. The criteria for sustainable development that lay basis for the CDM projects are already developed by the supreme council. A supreme body for the process of implementation of the CDM mechanisms is still to be identified. There are two options: the sustainable development commission or the cabinet of ministers. In order to ensure uninterrupted financing of the projects, it is imperative that the agreement on a decision-making body is made soon and the legal base for provision of certificates of reduced emission to the donor countries is in place during the year 2005 .

- In 2004 a joint 5 year project of UNDP/GEF-KfW and the Government of Georgia was commenced. The project aims at assisting the private sector players engaged in renewable energy projects. The project will facilitate to creation of working capital in the sector, preparation of new project proposals and preparation of the sector development strategy in cooperation with the Ministry of Energy. At the first stage few minor HESes will be rehabilitated and the project of provision of geothermal waters to Saburtalo district in Tbilisi will be financed. 
In 2004 project proposal for Georgia's Second National Notice on Climate Change, addressed to the Global Environment Protection Fund (GEPF) was prepared aimed at receiving financing from the GEPF. The proposal described the following priorities: vulnerability of mountainous regions to the anticipated changes in climate. For example the tendency of wilderness in Svaneti; vulnerability of some sectors of agriculture and water resources in Dedoplistskharo. For extremely vulnerable cases projects facilitating to adaptation to the changes need to be created and then financed. The key result of this three year project must be the maximal coverage of possible negative outcomes of the foreseeable changes in climate conditions.

\subsection{Development of agriculture}

More than half of economically active population of Georgia is engaged in agriculture, when slightly less than half of the population leaves in rural areas (based on the 2002 population census $-52.4 \%$ in urban and $47.6 \%$ in rural areas). Agriculture today takes a sizeable share both in domestic consumption and exports. The latter gives vital economic and social magnitude to agriculture and grants an important role to villages.

With a view of streamlining the agricultural sector as one of the priority directions of the economy of Georgia, the reorganization of the Ministry of Agriculture and the administrative-institutional reform of the sector is planned. The functions of the ministry will be consolidated into three key directions:

- Designing and implementing a sustainable development policy in the agricultural sector; developing and implementing priority public programs;

- Establishing public control on the use of agricultural resources, testing and conserving breeds, ensuring food security.

- Servicing the sector, which implies promoting business consultancy, the introduction of information technologies, providing scientific support and improving the qualification of specialists.

With a view of developing the agricultural sector the completion of land reform, which covers privatization and the creation of land market, is being envisaged. The establishment and development of the land cadastre and a single geographical computerized system of the use of natural resources and constructions in anticipated. The development of the land market will support the establishment of insurance and crediting systems in rural areas, which would be backed up by the formation of guarantee funds.

The development of infrastructure, production facilities, including the replenishment of the materialtechnical base and the introduction of modern technologies, is imperative in rural areas. Key attention shall be drawn on agricultural branches producing import substitute goods and export goods. The accessibility of loans for farmers and the processing industry will increase and micro financial schemes will be approved in accordance to the peculiarity of regions. The state will facilitate the availability of short and long-term seasonal lending proceedings to the agricultural sector projects through creating guarantee funds and promotional methods of lending to agriculture at the commercial banks to smooth out the seasonal effect. Vertical and horizontal cooperation of farmers and entrepreneurs shall be encouraged, namely: cooperation will be focused on sales, supporting capacities for the processing of agricultural goods locally, the diversification of the job market and availability of alternative employment opportunity in rural areas. Attention shall be drawn on rehabilitation of small and medium scale agricultural production.

Attention will be focused on projects for the mobilization of rural population and income enhancement that are based on corporate activities, thus creating ground for cultivating the mentality of voluntary cooperation in rural areas. 
Given the agriculture of Georgia largely concentrates on perennial cultures, the formation of insurance mechanisms shall be encouraged that will protect the producer from rapid adjustments and natural calamities.

The first stage in improving governance in the Ministry of Agriculture was carried out in 2002 when the central office downsized from 8 departments to 4 and cut its personnel by $20 \%$.

The reform also affected sub-agency organizations. The Drainage Basin Units of the Melioration Systems Management Department were downsized by 8 units, and from 2098 employees 648 were transferred to program financing, which led to less personnel on the payroll of the central budget.

A single service was established as a result of merging the Vegetation Protection and Phyto Sanitary Quarantine services. The Phyto Sanitary Quarantine Service was fully staffed, which allowed us to carry out staff reductions in the administrative office and discontinue the erroneous recruitment policy. During the past two years, the personnel of the Vegetation Protection Service was downsized by over 35 percent.

By merging the inspections on vegetal products, wheat and flour quality, sizeable staff reduction was affected.

On the base of the Procurement Service and the "SakTekZedamxedvaloba" Service as well as the Car Testing Ground, a single agro-engineering services was set up allowing for downsizing the personnel by 18 employees.

The preparation of documents for transforming the Melioration System Management Department into a legal entity of public law is in its final stage, which will eventually lead to a removal of 1444 employees from central budget financing.

A program to reform the Department of Livestock Breeding Issues has been developed, which will set apart regulatory and operating functions. Private structures will mostly be engaged in performing the latter function.

The Ministry developed a draft law on food safety, which calls for serious institutional changes in the system of the ministry. Namely, the merger of the Border-transport and veterinary-sanitary supervision unit of the Veterinary Department with the inspections on quality of agricultural products and flour aims at establishing a single service pursuant to European Union standards. The enforcement of these measures will increase the efficiency of the service and will lead to substantial downsizing.

The reform of the Veterinary Department has been launched, based on the program developed by Georgian experts, international specialists and NGOs. 5 laws and a sub-legislative act have been prepared to support the implementation of the reform. The program presentation was held in the Ministry of Agriculture and in regions. As a result of the reform, local budgets will be relieved of 2000 vets, whose payroll fund exceeds lari 850000 per annum. First time ever in the CIS, a private veterinary service and a network of labs will be established. The completion of the reform is anticipated in 2 years.

As a merger of the Vegetation Protection Service, inspections on testing selective achievements and the quality of seeds and seeding materials, a service shall be established with a single and strong regulatory function that will transfer economic responsibilities into private management. The production of seeds, seeding material and breeding livestock of public priority shall be transferred to private structures through assisting them with the receipt of licensees and permits and other practical matters.

A commission under the Ministry charged to harmonize the present legislation with the EU legislation, developed and submitted to the chancellery the package of legislative amendments that need to be introduced for meeting EU standards and regulations. 
Reforms in progress in the Ministry aim at transferring economic functions to the private sector and by changing the legal-organizational status relieving the central budget of dependent sub-agency organizations and respective personnel.

With the cooperation of the EC TACIS program the creation of a new centralized budget and financial management system is being carried out, which will facilitate an efficient planning of 2006-07 measures for the development of priority directions of the agricultural sector in the framework of the EDPRP.

The draft state budget 2005 envisages 15 program measures, of which 10 targeted programs and 5 programs funded by international organizations:

\begin{tabular}{|l|l|}
\hline$\#$ & \multicolumn{1}{|c|}{ Programs } \\
\hline 1 & Water management for food security (complex development of land melioration) \\
\hline 2 & Measures preventing epizooty \\
\hline 3 & Protection of Vegetation \\
\hline 4 & Restoring cattle breeding, poultry and apiculture \\
\hline 5 & Measures for the improvement of acid soils and steep lands \\
\hline 6 & Protecting the soils of Georgia from erosion \\
\hline 7 & Tea (rehabilitation of tea cultivation) \\
\hline 8 & Logging and rehabilitating fish of valuable endangered species in internal waters of Georgia \\
\hline 9 & Organizing and implementing monitoring over the quality of good products \\
\hline 10 & Determining zones and borders of sources of mineral waters \\
\hline 11 & Project of Organizations of Irrigation and Drainage Consumers (WB) \\
\hline 12 & Ministry of Agriculture Development Project (WB-ADP) \\
\hline 13 & Agricultural survey, training and introducing of consultancy (WB-ARET) \\
\hline 14 & Program of Developing Mountain and Highly Mountainous Regions (IFAD) \\
\hline 15 & Preparatory Project for the Development of Agriculture (WB) \\
\hline
\end{tabular}

According to the official statistics, poverty level in rural arrears continues to increase. In order to increase revenues of the self sustainable peasants' households and assist them, a new paragraph was added to the Agriculture Development Strategy. The new paragraph states: "Special attention shall be given to public mobilization and revenue enhancement projects in the villages that are based on joint responsibility and lay grounds for creation of a mentality of voluntary cooperation"

The direct as well as indirect beneficiaries of the 2004-2005 budgeted programs of the Ministry of Agriculture are the peasants' households oriented on self sustainability. More attention will be granted to similar project in the budgets for the years 2006-2007.

Aimed at supporting the aforementioned groups the Ministry is already implementing a number of projects. Among them are:

The International Fund for Agricultural Development (IFAD) project on Rural development Project for Mountainous regions. It consists in the following components:

- Assistance of procession of the agricultural produce locally as well as its trade;

- Assistance of development of rural financial institutes;

- Improvement of qualitative and quantitative indicators of agricultural produce;

- Rehabilitation of village infrastructure.

World Bank financed agricultural development project. One of its components is development of credit unions.

Utilizing the Japanese grant (2KR) money deposited at the special account of the NBG a service center for machinery and equipment used in agriculture was established in 2004. This service center will service the equipment of the self-sustainable households. 
As a result of colese cooperation with the EU, the 2004-2005 action plan of TACIS include financing of a pilot project "Poverty Reduction in Kvemo Kartli and Samtskhe Javakheti". The project will be implemented in 2005-2008. The aims and priorities of the project are the following:

- Assistance of social and economic development in rural areas;

- Establishment of a sustainable partnership among the central government, local management, as well as municipalities and civil public for the purposes of planning and implementation of economic and social activities, that will lead to improving living conditions in rural areas;

- Enhancing potential as well as the role and functions of the local managements and population in the process of planning, implementation and management of the economic development programs;

- Reduction of social and ethnic tension in selected regions;

The afore-mentioned project plans to assist the measures leading to revenue increase for local farmers; This initiative will touch plant-growing, cattle-breeding, fish breeding, food procession, dairy, beebreeding and honey-yielding industries; as well as facilitate to development in forestry, pasture farming, domestic farming, rural tourism and other similar activities;

It is planned to create task forces that will assist establishment of cooperatives and farmers' organizations in rural areas. This initiative will ultimately result in improvement of living conditions in villages; enhancement of quality of agricultural produce by increasing availability of credits and technologies to the farmers.

The project will assist by establishing connections/links between the small farmers and the processors, finding alternative markets and facilitating to dialog/consultations between population and the local management; as well as dialog between the local and central government.

Training courses and a series of seminars will be held for the purposes of enhancing professional capabilities in rural areas and presenting new technologies. Training in Georgian language will also be held for different ethnical groups of population.

\subsection{Energy sector}

With a view of improving the situation in the energy sector of Georgia, the rehabilitation of the infrastructure, the improvement of energy generation and transportation and the reduction of energy loss is planned. With close consultation with donors, the energy sector action plan was developed, which covers the following directions: improving the management and operations of the sector, improving cash collection rates and implementing energy sector projects supported by international assistance. The strategic action plan envisages the implementation of a set of measures, including:

- A set of measures to improve cash collection was identified. These measures will improve cash collection rates from industries and from state organizations as well as from population in Tbilisi and other regions of Georgia. As a result of effective implementation of these measures cash collection rates in Tbilisi as well as in the regions will increase considerably. The outlets for cash collection will be established in villages. These outlets will be equipped with modern computer systems. The program of installment of the electricity meters will be further enhanced during the following years. As a result of the implementation and administration of the targeted measures within the planned timeframe the cash collection rates will improve (from 55-60\% at present) to $75-80 \%$ by the end 2006 .

- The Georgian State Electricity System plans to reduce the loss from 11 to 10 or even less percent (anticipates to reduce it to 6 percent in future) through eliminating corruption, installing meters and assuming measures to protect the system;

- To streamline the current legislation, a draft law on Criminal Prosecution of Electricity Theft has been submitted to the parliament; 
- A legislative initiative has been developed to address energy sector debts, the Debt Restructuring Agency has been set up with the financing of the KFW;

- The energy sector will adopt international accounting standards, which will ensure the transparency of its activities. In April 2005, the government of Georgia will come up with a schedule for the implementation of the above-mentioned measure.

To regularize the sector, the GNERC requested the assistance of international consultants to study the tariff methodology, and proposed that due to the specific situation in Georgia and proceeding from international experience, the authority and independence of the GNERC must be clearly reflected in the Georgian legislation. The government supports the initiative and plans to closely cooperate with the GNERC and its consultants on the matter.

The key issue of energy security is the rehabilitation of the transmission line, as well as ensuring the activity of EngurHES and protecting its stability. The latter requires some US\$60 million, of which the EBRD already extended US\$38 million.

An important project to be offered to potential investors is the construction of the KhudonHES. The operation of the HES will satisfy the energy demand of the country with internal resources for the duration of the entire year. KhudonHES may generate 1 billion kwh and allow EngurHES to additionally generate 1 billion kwh given the KhudonHES dam will be constructed above the EngurHES on the same river. The construction of KhudonHES requires US\$500-600 and will last for 5-6 years. The investor should commit to selling the generated electricity in the winter season to Georgia and exporting it in spring-summer season.

Implementing the privatization effectively is one of the key directions of the energy sector strategy. According to the action plan, all energy entities are subject to privatization save dispatching entities. The privatization plan is anticipated as follows: at the first stage the distribution sector will be privatized. The privatization of the UDC in full or by regions is a priority. In the case of the latter, distribution companies in regions with the lowest cash collection rates must be privatized first. When electricity distribution is privatized, cash collection rates will increase and payments to the WEM will be high. The second stage of privatization deals with hydroelectric stations. As of today the situation in the HESs is bleak. In order to make the generation sector attractive for potential investors, several criteria for offering the selling price of HESs is being considered. According to the privatization plan, stage first anticipates conducting preparatory works on HESs for the period of 2 years so that the sector of generation looks competitive for potential investors.

From a set of strategic measures in the sector, the deregulation of small HESs is very important. Ten small HESs currently operating in Georgia will be able to come out of the single energy balance and will have freedom of options when selling generated electricity. The process of deregulation will support the construction of new entities, the pulling of investors, establishment of market relations and the creation of a healthy competitive environment.

Georgia, proceeding from its strategic location, has the advantage of making a choice for gas transit between the North-South and East-West transit lines. The benefit of this advantage will remain in force until the internal system will face an irreversible collapse. The country will have to identify needed funds to lead the system out of the collapse and receive maximum profits owing to strategic location.

The East-West transit line, which envisages transporting gas through the Shah-Deniz main line and selling it in Turkey, offers Georgia an opportunity of participating in agreements on purchase and sale. A respective agreement was concluded with the Shah-Deniz Consortium, which envisages gas supply from 2006.

Georgia has no facility to store gas, therefore gas supply will have to be totally balanced by suppliers. The construction of a reservoir requires US\$40-45 million. It is possible to balance the gas supply when you deal with a single supplier, but in the case of Shah-Deniz it will be more complicated. For Georgia's capacity it will be better to resort to a single supplier model. Pursuant to this scheme only 
one organization will supply gas both from Russia (through Gazprom, Itera and others) and Azerbaijan (Shah-Deniz Consortium, SOCAR and other), as well as from own gas wells, which are currently being researched.

The study conducted by the WB and the TACIS concluded that the gas transmission system is in a very poor condition and requires immediate investment of US\$40 million. Without channeling this money, the system might collapse in 2007-2008, depriving Georgia from key economic and social development resources.

\subsection{Reforms in the Ministry of Justice}

\section{- Legislative sphere}

Currently draft laws on civil service, local self-government, administrative-territorial arrangement, restitution of property and residential place of victims from the Georgian-Ossetians conflict zone, criminal prosecution of legal entities, notary, bankruptcy, activity of a private arbitrage, collateral and registration of rights on real and immovable property, criminal procedures code and the new code of administrative offences are being developed.

\section{- Penitentiary system}

A legislative package is being developed to eliminate corruption and improve the condition of prisoners in the penitentiary system.

In the nearest two months the construction of a new jail to replace the old Ksani penal colony is planned.

In May 2005 the construction of a new prison for 1000 inmates will be completed in Kutaisi.

In Summer 2005, a new prison for 800 inmates will open in Rustavi with the financial assistance and cooperation of the European Union. The new jail will serve as a model penitentiary institution equipped by international standards.

A modern jail for 110 female inmates will be opened by end 2004 .

A new jail for 100 underage inmates will be operational in January 2005.

By June 2005, the rehabilitation program for all jails and penal colonies will be completed, which will allow for determining future plans for a realistic reform of the penitentiary system, of which the optimization of the system and improving its management are very important.

By 2005 the computerization of the penitentiary system will be completed and an adequate database will be created.

The reform also envisages a gradual move from a penal colony system to a cell system and the introduction of essential security systems in prisons of special regime.

\section{- Execution}

The transformation of the Execution Department into a legal entity of public law is planned in 2004, which will increase the level of salaries and will facilitate the operation of the execution system as a whole. The execution system will be computerized and training of personnel will be carried out nationwide.

\section{- Public register}

The Ministry of Justice embarked on the creation of a single public register. Its aim is to consolidate the information into a database and make it accessible to each citizen in a reasonable time. This measure will cut corruption in the system. As a result of setting up a public register, it will be possible to compile reliable voter lists as well as lists of taxpayers, pensioners and other beneficiaries. 
The single public register will cover: civil, public, legal entities (other than business), political unions, controlling bodies, licensing and permits and normative act registers.

\section{Civil Register}

The civil register concept has been built on providing a one-stop-shop type of service and is associated with developing programs for a digital government. As result of the reform, public service will become rapid, efficient and of high quality.

\section{Public register}

On the base of the Land Management Department a national agency of the public register has been created, which is responsible for creating and maintaining a single computerized cadastre system and registering property rights on real and immovable estate.

Core adjustments will take place in the system, including structural realignment, the operation of a public service oriented on citizens, training staff recruited on competitive terms, the creation of a flexible and transparent registration system, the establishment of a center maintaining cadastre information, creating simplified rules for title ownership services and offering services of a better quality as a whole. After accessing data and information from bureaus of technical inventorying, the agency shall be able to offer a simplified procedure for registering ownership rights. In the nearest future a single computerized network linking 80 territorial bodies will be created.

\section{- Modern expertise center}

Currently work is underway to establish an expertise center that would meet modern standards and will feature advanced technologies and equipment.

In the nearest future a finger print program will be set up (the database will be able to identify a matching print in 15 minutes, which will allow law enforcers to rapidly unveil cases of crime).

The US Justice Department will provide three containers to the expertise center, with different labs, safety equipment and other resources. As a result Georgia will have the most advanced forensic laboratory in the FSU.

\section{- The notary}

The Ministry of Justice is actively engaged in improving the performance of the notary. The reform aims at enhancing the professional image of notaries as in other Latin-notary countries. To achieve this goal, the criteria for becoming a notary must be revised through legislative amendments, requirement for regular training must be established, the accountability of notaries must be raised and compulsory insurance of notaries must be introduced to safeguard citizens. In future, notaries should also be covered by the computerized single public register.

\section{Social and economic rehabilitation of post conflict zones}

Pursuant to the Presidential Decree, in April 2004 the State Minister's office in charge of conflict resolution was introduced. The office is closely engaged in current and future rehabilitation programs for conflict zones that have been supported by international organizations, as well as projects targeting IDPs.

On January 31, 2004, a protocol was signed on the third rehabilitation program in the zone of Georgian-Ossetians conflict supported by the EC. It envisages performing works of 2.5 million Euros in energy, water supply and social spheres. The program, which will be implemented by the UNDP and the UN High Commissioner for Refugees, includes three stages:

- Constructing housing for potential repatriates in Tskhinvali region and providing them with essential goods (800,000 euros) 
- rehabilitating the key infrastructure in the region with beneficiaries among both Georgian and Ossetians population (1,300,000 euros)

- rehabilitating infrastructure buildings on places of IDP settlements (400,000 euros)

The program has been launched. The Georgian-Ossetians organization committee under the OSCE is coordinating the program. The Georgian delegation is headed by the representative of the State Minister's office.

Furthermore, together with the State Minister's office in charge of facilitating small and medium scale business, specific projects to support the development of entrepreneurship in the conflict zone are being prepared. The Government of Georgia intends to explore with OSCE and European Commision possible donor support for these problems (a statement was made on November 5, 2004 in Sochi during the meeting between the Prime Minister of Georgia and the de-facto leader of South Ossetia).

The European Commission earmarked 4 million euros to the rehabilitation of the Georgian-Abkhaz conflict zone. The works include:

- utilization of waste and water pipes;

- rehabilitation of 4 hospitals in Abkhazia and adjacent territories of West Georgia;

- fortifying embankments of river Kodori to prevent floods

With the financing of the EC and the UNDP program, the implementation of social rehabilitation programs is planned in Gali region and adjacent territories, namely Ochamchire and Tkvarcheli. In the initial stage, the following branches and directions must be promoted: agriculture and the production of agricultural goods; the utilization of timber and natural resources; rehabilitation of residential and communal infrastructure; education, small business, telecommunication and information management, development of institutional capacities and the integration of IDPs.

The implementation of the program will lead to the economic and social recovery of the region. It will establish conditions for the return of refugees and will facilitate peace-keeping processes. However, the implementation of the program depends on the scope of further developments.

Refugees from the conflict zone are socially most vulnerable. Thereby providing social assistance to the IDPs is a critical issue. To implement specific programs in this direction, the government of Georgia, as well as a number of international organizations and donors have pulled substantial resources in the past decade.

The new approach program, a joint initiative of the USAID, Swiss Agency, OCHA, WB, UNDP and the UN High Commissioner for refugees, was launched in 1999 and has been of paramount importance.

The new approach, acknowledges the inalienable right of refugees to return to their homes and believes that the categorization of the IDP status should not lead to their marginalization (political, social and economic) at their temporary residence.

The program currently aims at temporary integration of refugees and due to the social vulnerability of Georgia envisages providing their host families and refugees themselves with social and economic, transitional and development-oriented assistance on the spot.

The new approach is a pilot program, which will be carried in three stages throughout 1999-2005. The first two stages of the program have been completed and it currently entered the concluding phase.

US\$ 743349 have been spent as of spring 2004 of which US\$ 290760 were consumed by stage 1 and 2 of UNDP financed projected, oriented mainly on developing agriculture and communities, self subsistence, social integration and technical procurement in Samegrelo and Imereti regions. US\$ 466 388 have been earmarked in 2004-2005 to implement stage 3 of the program.

Currently several projects are underway envisaging the reconstruction of collective residential centers for refugees, the development of small-scale business and the mobilization of communities. 
The government of Georgia is interested in the efficient use of resources earmarked within the program and believes that efforts must be directed on improving social and economic conditions of host families and refugees in real terms, as well as on facilitating small business development and self-subsistence.

\section{The status of EDPRP measures in 2004}

In line with projected revenues needed to finance state budget expenditures, the structure of 2004 state budget expenditures has been developed in a way to accommodate social protection measures to the maximum, including priorities outlined in the EDPRP. At the same time, as permitted by available resources the funding of priority directions required for steady development have been increased, such as: defense, public order and state security.

When reviewing the 2004 state budget, we see that budget expenditures match with measures envisaged by the EDPRP in some of the key sectors outlined in the program. In some cases (e.g. social protection and pensions) the 2004 state budget earmarks more funds to finance measures envisaged by the EDPRP. However, some measures failed to receive funding in volumes determined by the EDPRP. The latter was prompted by the fact, that bulk of funds in the 2004 state budget were directed to repay arrears of previous years (the repayment of arrears concerned spheres for which financing is outlined in the EDPRP). In addition, substantial funds were directed to strengthen defense capacities of the country.

Please find below how the 2004 state budget finances sectors outlined by the EDPRP:

Social protection and pensions - according to the EDPRP, the state budget had to envisage lari 289 million in total for social protection and pensions. The budget law foresees lari 365.5 million or 26.4 percent over the EDPRP projection. Budget 2004 finances important measures such as pensions, benefits and allowances in the amount of lari 280.8 million, of which lari 224.3 million are directed to pensions. Substantial funds are foreseen to repay pension arrears of previous years totaling to lari 76.7 million, of which lari 4 million for the execution of court orders.

Healthcare - the total volume of funding state healthcare insurance programs made lari 93.4 million, which is lari 3 million over EDPRP projections. The budget law envisages lari 14.7 million and lari 56.8 million for out and inpatient care respectively. lari 8.6 million have been allotted to providing special patients with medicines, and lari 7 million to facilitate the institutional and functional reform of the social sphere.

Education - according to the EDPRP the state budget had to foresee lari 61.1 million for funding education whereas the state budget 2004 envisages only lari 42.2 million (excluding incomes of high education establishments for levying fees on tuition). While reviewing the education sector we have to take note of large-scale measures that were assumed in 2002-2004 that led to increasing salaries by average 60-65 percent in the sector. In 2004 salary arrears of education sector employees in the amount of lari 17 million were fully repaid.

$\underline{\text { Energy }}$ - the state budget 2004 also concentrated on the energy sector, which has been acknowledged as a priority by the EDPRP. The state budget envisaged lari 63.9 million for the energy sector, which is lari 1.8 million over EDPRP projections.

Transport and communication - the state budget envisaged lari 46.4 million according to measures outlined by the EDPRP (which is lari 10.3 million less than projected by the program). The funds are fully directed to maintain roads. The budget 2004 envisages the financing of such measures that are not included in the EDPRP at all, namely lari 5.6 million to pay arrears on compensations for road construction works performed in previous years, measures to cope with the consequences of natural calamities lari 9 million and etc.


million when the program projected lari 29.5 million (lari 4.7 million more). 
$\underline{\text { Tourism }}$ - to facilitate the development of this sector, the state has assigned lari 0.7 million for funding targeted programs (which is lari 0.2 million less than the EDPRP projection).

Environmental protection, forestry resources and land management - the budget 2004 had to assign lari 6.6 million to finance measures outlined by the EDPRP whereas the assignment in 2004 makes lari 6.9 million.

Other measures - for funding other measures foreseen by the EDPRP the state budget 2004 had to assign lari 13.4 million whereas in reality only lari 4.4 million have been envisaged, directed to cofinancing investment projects.

The review was drawn using budget resources of the state budget and assignments pursuant to the EDPRP given in column "state budget". The review does not measure up expenditures financed by external sources and expenditures of the state budget (to be executed via external funding) and investment projects (funded by foreign grants). The state budget 2004 envisages the financing of EDPRP measures at only 64.2 percent (lari 313.64 million had to be assigned pursuant to the program in 2004). In here the fluctuation of the lari exchange rate must be noted, given the volume of funding for EDPRP measures will need to be adjusted accordingly.

When comparing the 2004 state budget to the EDPRP, the state budget envisages substantial funds for spheres that are also outlined in the EDPRP. Given these specific measures were not included in the detailed expenditure breakdown of the EDPRP, they have not been reflected in the present progress report. The budget 2004 assigned substantial funds for the repayment of arrears of previous years (total of lari 186.7 million). The repayment of arrears concerns sectors that are regarded as priority by the EDPRP.

Proceeding from the afore-mentioned, the EDPRP measures must be revised and adjusted to current developments in the country while accommodating new priorities set by the President and the government of Georgia.

Unlike the previous budgets, in 2004 the state budget significantly increased financing for such spheres as defense, public order and national security, all amounting to 13.8 percent of total budget expenditures (lari 266.8 million)

In overall, the state budget had to envisage lari 610.1 million for programs and measures outlined by the EDPRP, however in reality the state budget assigned lari 41 million more to the funding of the above-mentioned i.e. lari 651.1 million.

\section{The consistency of the draft state budget 2005 with EDPRP measures}

The government of Georgia developed the Law of Georgia on the draft state budget 2005 in conformity with rules determined by the Budget System Law of Georgia and the Parliament of Georgia approved the Law on 2005 State Budget on December 28, 2004;

The GDP growth rate is planned at 6 percent in 2005, which is consistent with the EDPRP growth rate of the GDP. The law on budget 2005 envisages expenditures of lari 2260784.0 thousand, which is 294010 thousand more than the 2004 budget figure approved by the August amendment of the State budget law. The growth rate comprised $14.9 \%$.

As did the budgets of the last years, the law on budget 2005 assigns substantial funds for financing social protection measures. For the first time in the past decade, lari 140.5 million have been envisaged to repay arrears of previous years, which allows for the repayment of wage and pension arrears to the maximum. The draft budget 2005 also concentrates on adequate financing of national defense measures.

Please find below how the 2005 state budget finances sectors outlined by the EDPRP: 
Social protection and pensions - according to the EDPRP, the budget 2005 has to assign lari 332 million (budgetary sources) for the social protection and pensions whereas the draft 2005 budget law envisages lari 443.4 million, which is lari 111.4 million more than EDPRP projections. It is worth noting that the minimum pension will be doubled from 2005 and the state budget does envisage the relevant allocations. The assignations for the social sector envisage financing of the important measures such as: pensions, assistances and benefits by lari 410.4 million. Among them Lari 348.7 million will be directed to pay current pensions. Full repayment of the pension debt is planned.

We have no note the monetization of different benefits anticipated by the legislation in 2005, namely, the President and government of Georgia decided to abolish concessions granted for different citizens and issue a cash benefit to households below the poverty line. The draft budget 2005 envisages lari 26.0 million for this purpose; among them 10 million will be utilized for monetization of electricity consumption benefits for the aforementioned part of population. As for other benefits that are revoked, the respective local budgets will allocate compensatory payments.

Healthcare - the draft budget 2005 assigns lari 107.9 million (budgetary sources) to finance state healthcare insurance programs, which is 103.6 percent of the sum outlined by the EDPRP. For in and outpatient care the draft budget assigns lari 19.7 million and 63.4 million respectively, lari 10.1 million have been allotted for providing special patients with medicines, and lari 8.1 million to facilitate the institutional and functional reform of the social sphere.

Education - according to the EDPRP the state budget 2005 had to foresee lari 67.8 million for funding education whereas the state budget 2005 assigns only lari 35.7 million (excluding funds incomes of high education establishments for levying fees on tuition). By the end of the year the Parliament of Georgia approved the law on high education that will form the basis for the educational reform in the country. The budget 2005 does envisage financial support of the country's educational program.

Energy - the state budget 2005 envisages lari 35.5 million (budgetary sources) for the energy sector of which lari 22.0 million to finance the cost of the energy supplied to Georgia energy wholesale market by HESes. According to the EDPRP, the energy sector had to received twice more i.e. lari 71.1 million, including lari 46.1 million to pay for energy consumption by budget organizations and social vulnerable groups of the population. The energy consumption payments of budget organizations are included in expenditures of respective spending units, thereby it is hard for us to measure the total volume so we have not included them in the progress report. As for payments for electricity consumption by vulnerable groups, as we mentioned above, from 2005, concessions, on which on electricity consumption, will be revoked and cash compensations will be paid out instead. The budget includes adequate assignments for the financial provision of the cash benefits.

We must note that in 2005 revenues from privatization will exceed the targeted parameter and the large share of the incremental revenues will be directed to finance the energy sector (at least lari 40 million). This will facilitate to salvation of energy problem in the country.

Transport and communication - the state budget envisages lari 76.9 million according to measures outlined by the EDPRP (which is lari 14.5 million more than projected by the program). The funds are directed to maintain roads (lari 60.4 million) and to subsidize the Georgian TV and Radio Broadcasting (lari 16.5 million).

Agriculture and food - The EDPRP outlined 26 measures in 2005 totaling to lari 28.4 million. The state budget 2005 envisages the funding of 13 EDPRP projects in the amount of lari 18.9 million (budgetary sources) Thus, the agricultural sector will be financed (jointly budgetary and foreign sources) by 2.7 million lari less then it was envisaged. But the budgetary financing only is 9.5 million less then it was envisaged. 
Environmental protection, forestry resources and land management - the budget 2005 had to assign lari 4.9 million to finance measures outlined by the EDPRP whereas the assignment in 2005 makes lari 4.6 million.

Other measures - for funding other measures foreseen by the EDPRP, the draft state budget 2005 had to assign lari 13.8 million for financing 5 measures. The state budget 2005 does not provide any funding for these measures. However, the 2005 state budget anticipates to fund some EDPRP measures, which are not scheduled for 2005 by the program. The lari 140.5 million envisaged by the budget 2005 to repay arrears are included under "other measures" by the present progress report.

The review was drawn using budget resources of the state budget and assignments pursuant to the EDPRP given in column "state budget". The review does not measure up expenditures financed by external sources and expenditures of the state budget (to be executed via external funding) and investment projects (funded by foreign grants). The draft state budget 2005 envisages lari 24.5 million less funding for EDPRP measures (lari 278 million had to be assigned pursuant to the program in 2005). Hereby, the fluctuation of the lari exchange rate must be noted given the volume of funding for EDPRP measures will need to be adjusted accordingly.

When comparing the 2005 state budget to the EDPRP, the state budget envisages substantial funds for spheres that are also outlined in the EDPRP. Given these specific measures were not included in the detailed expenditure breakdown of the EDPRP, they have not been reflected in the present progress report. As in 2004, the draft budget 2005 assigned substantial funds for the repayment of arrears stemming from previous years. The repayment of arrears concerns sectors that are regarded as priority by the EDPRP.

Proceeding from the afore-mentioned, the EDPRP measures must be revised and adjusted to current developments in the country while accommodating new priorities set by the President and the government of Georgia. Due to lari exchange rate fluctuation, adjustments must be introduced to financial resources expected from foreign sources to fund program measures.

When talking about the budget 2005, we must note that in budgets 2004-2005 the spending significantly increased on spheres such as defense, public order and national security.

In overall, the 2005 state budget had to envisage lari 685.7 million for programs and measures outlined by the EDPRP, however the budget law envisages lari 190.2 million more or lari 875.9 million (including arrears payment of lari 140.5 million).

\section{Medium Term Expenditure Framework (MTEF)}

To ensure an efficient and timely implementation of the EDPRP, the connection between annual state budgets and the program must be very tight. With this in mind, the Ministry of Finance, the Ministry of Economic Development and other appropriate agencies plan to develop medium term (3-year) macroeconomic and fiscal projections. The Ministry of Finance has already developed key principles and mechanisms for medium term expenditure planning, which will aim at two interconnected processes:

- top down principle - determining national priorities and developing medium term expenditure ceilings for each spending unit proceeding from macroeconomic parameters and realistic revenue projections;

- bottom up principle - development of an outline for medium term expenditures by spending units based on sectoral strategies with a clear and reasonable expenditure breakdown

The MTEF provides a multi-annual dimension to the annual budget preparation process (in case of Georgia a 3-year framework, including the annul budget and projections for two consecutive years, which is totally consistent with the EDPRP format) and will link and coordinate the two processes/principles. 
The enacted Budget System Law already requires the government to make a shift towards medium term planning, namely the development of a medium term macroeconomic framework, medium term fiscal projection and tax policy for the consecutive two years. The draft 2005 budget includes a special form, which requires spending units to submit information by specifying the goals and indicators of measures/programs. Despite this legislative innovation and steps actually taken forward in this direction, this approach has not been introduced into practice so far, though the development of a medium term expenditure framework will certainly facilitate it.

When introducing the MTEF the priorities of the government towards the EDPRP and other strategic documents must be determined. Each year, government priorities must be adjusted reflecting the achieved progress with due consideration given to social-economic conditions at hand.

At the following stage, the MoF must come up with a package of total available resources building on prudent macroeconomic projections. The process will be based on the medium term macroeconomic framework and the medium term fiscal framework.

The development of the MTEF as an efficient mechanism in the process of making decisions on the distribution of available resources requires a discreet and formalized approach. The key directions of budget and tax policy will be used by spending units to prepare sectoral expenditure frameworks. Subsequently, the MoF will prepare the final MTEF with a final ceiling, based on which spending units will produce a final sectoral medium term expenditure framework and the annual budget. The developed MTEF will be discussed and adopted by the cabinet of ministers.

While determining ceilings, the EDPRP will serve as a framework paper as it reflects main socialeconomic directions. The latter must be transformed into sectoral budgets and sectoral measures in the process of planning medium term expenditures.

The following components are central to the development of the MTEF:

- statement of a sectoral strategy - key goals, strategies to be implemented individually in sectors, which should be in full conformity with the sectoral priorities outlined by the EDPRP. The latter will ensure a tight exchange between national interests and the MTEF;

- determining appropriate measures to achieve afore mentioned goals while specifying results and indicators;

- producing a 3-year expenditure breakdown for each program outlining current and investment expenditures;

- the prioritization of identified measures envisaging preliminary ceilings

The product of the afore mentioned process is the preliminary sectoral expenditure framework based on which the MoF will prepare the MTEF.

With a view of coordinating and monitoring the process of medium term expenditure planning, a special commission shall be set up chaired by the Minister of Finance and composed of Deputy Finance Ministers. In addition, the commission will consist of the Minister of Economic Development, the State Minister in charge of European integration issues and deputy ministers from other ministries.

Working groups shall be set up in line ministries to develop the sectoral strategy, identify relevant priorities and coordinate the process of producing the expenditure breakdown. Envisaging the capacity and potential of ministries, the development of the MTEF shall be carried out by stages. At the same time, to streamline the process, the institutional strengthening of ministries and personnel training in planning is anticipated.

Pursuant to the current plan, the first MTEF shall be developed in 2005 to cover years 2006-2008. The document will include detailed medium term expenditure plans by sectors produced by pilot ministries. Non-pilot ministries shall be presented with less detailed information. This ambitious statement requires the creation of sector working groups in the nearest future, so that development of sector strategies are concluded by H1-05. 


\section{Coordination, monitoring and assessment of the program implementation process}

The Ministry of Economy of Georgia is in charge of coordination and monitoring of the EDPRP implementation process. There is a special department within the ministry to carry out these duties. Besides, to make the implementation of this function more effective, and to improve coordination among the ministries and different state bodies there is a UN project named "Support to EDPRP Implementation". The independent experts working in the framework of the UN project closely cooperate with the poverty reduction department of the Ministry and with other entities that are related to the process of implementation of the EDPRP.

As it was mentioned above, the government of Georgia intends to prepare a three year work plan that will be approved by the cabinet of ministers and will be reflected in EDPRP; The mid-term expenditure framework is also planned to be developed; the stated two processes will be lead in close cooperation of the Ministry of Economic Development and the Ministry of Finance of Georgia to ensure that the prepared action plan is maximally realistic and the planned reforms are implemented effectively and in time.

Besides the Ministry of Economic development in coordination with other ministries and other relevant agencies ensures close monitoring of the process of implementation of the measures envisaged by the EDPRP and the present report in 2005. Observing the participation principle and based on consultations with the civil society a Progress Report will be prepared by the end 2005 describing developments of the measures planned for 2005. The Progress Report will be available for public discussion as well as for discussion by the international organizations. Besides, the EDPRP communication strategy envisages provision of information on important measures planned within the EDPRP framework and results of these measures to wide public.

In 2003 work was launched to pull the set of indicators on the monitoring and assessment of the EDPRP into a single system and make it accessible for users. Consequently, the DevInfo database program, designed to monitor progress towards UN MDG was chosen.

Devinfo is the advanced version of Childinfo. Given the government of Georgia committed to harmonizing EDPRP and MDG indicators, DevInfo may be used as an efficient facility to monitor progress against both programs. A suggestion was made that DevInfo could be used for the assessment and monitoring of the EDPRP progress and a new software, namely GeoInfo could be developed on its base to provide coverage to all three fundamental programs in Georgia, such as the MDGR, the EDPRP and the NPA (National Plan of Action for Children).

Work has been planned to implement the suggestion, which include the following stages:

1. the classification of all three sets of indicators and studying their intersection. The work was partially carried out while developing the EDPRP when the indicators of the MDG and EDPRP were combined, however several adjustments and revisions must be introduced and the NPA program must be included in the database.

2. the estimated source of information for each indicator and the capacity to calculate each indicator must be determined. The possible length of the dynamic row and the approximate level of desegregation must be identified. Problems in calculating each indicator must be found.

3. problems must be classified in accordance to activities and institutions so that accountability could be identified and the current status of assessment and monitoring could be generated, which would expose both negative and positive developments.

4. the substance of the problem will be formulated and ways of problem solution shall be analyzed. At this stage, specific measures to tackle the problem will be identified, the means of implementation and estimated results (if implemented) shall be assessed. 
5. based on the available indicators a database shall be constructed, and for those indicators that cannot be computed, they will be represented by an empty cell pending possible computation (if at all possible)

The first two stages, the most labor-consuming, are practically completed and work under stage 3 is underway and is expected to conclude in the nearest future. Simultaneously, implementation of the stages 4 and 5 has been launched.

\section{Participation}

As it was mentioned above, the intergovernmental working group that included representatives from ministries, government agencies and independent experts, financed by the UNDP, was set up to prepare this report. The Ministry of Economic Development coordinated the process.

As the first stage an outline and a brief overview of the report was prepared that was subject of discussion among many interested parties. We shall note that the resident representations of the International Monetary Fund and the World Bank have been involved in the process from the very beginning.

The report was assembled based on the materials provided by the parties represented in the working group. On December $14^{\text {th }}$ and $15^{\text {th }}$ the report was presented to the public. The first day discussions focused on the report review and discussion of further plans with the representatives of the public sector, and different NGOs working in private sector. The NGOs that were actively involved in the process of preparation of the EDPRP comprised majority of the meeting participants.

We welcome the fact that the representatives of international organizations and donor countries, united under the name of "donors" still express active interest in the EDPRP implementation process. The December 15th meeting was with the Donor's group.

The members of the aforementioned intergovernmental working group, representatives of different ministries and the state agencies were involved in the process of discussions/elaboration of the comments and suggestions received during the presentations. The number of changes were introduced to the draft as a result of the working process and the final version of the document was prepared which is also placed on the web site of the Ministry of Economic Development at www.economy.ge 
Selected economic and financial indicators

\begin{tabular}{|c|c|c|c|c|c|c|c|c|}
\hline & $\begin{array}{l}2001 \\
\text { Actual }\end{array}$ & $\begin{array}{l}2002 \\
\text { Actual }\end{array}$ & $\begin{array}{r}2003 \\
\text { Actual }\end{array}$ & $\begin{array}{l}200 \\
\text { Forec } \\
\text { Project }\end{array}$ & $\begin{array}{l}04 \\
\text { cast } \\
\text { expected }\end{array}$ & $\begin{array}{l}2005 \\
\text { Forecast }\end{array}$ & $\begin{array}{r}2006 \\
\text { Forecast }\end{array}$ & $\begin{array}{r}2007 \\
\text { Forecast }\end{array}$ \\
\hline \multicolumn{6}{|c|}{ (Percentage change relative to previous year, unless otherwise indicated) } & & & \\
\hline \multicolumn{9}{|l|}{ National income and prices } \\
\hline Nominal GDP & $10.5 \%$ & $12.2 \%$ & $14.9 \%$ & $13.9 \%$ & $13.9 \%$ & $10.8 \%$ & $10.5 \%$ & $9.4 \%$ \\
\hline Real GDP & $4.9 \%$ & $5.5 \%$ & $11.1 \%$ & $8.5 \%$ & $8.5 \%$ & $6.0 \%$ & $6.0 \%$ & $6.0 \%$ \\
\hline Nominal GDP( million GEL) & 6647.1 & 7455.5 & 8565.5 & 9758.2 & 9758.2 & 10809.2 & 11942.1 & 13066.8 \\
\hline Consumer price index, period average & $6.2 \%$ & $6.7 \%$ & $4.7 \%$ & $5.8 \%$ & $5.8 \%$ & $5.5 \%$ & $5.0 \%$ & $5.0 \%$ \\
\hline Consumer price index, end of period & $3.4 \%$ & $5.4 \%$ & $7.0 \%$ & $5.3 \%$ & $5.6 \%$ & $5.2 \%$ & $5.0 \%$ & $5.0 \%$ \\
\hline GDP deflator & $5.3 \%$ & $6.3 \%$ & $3.4 \%$ & $5.0 \%$ & $5.0 \%$ & $4.5 \%$ & $4.2 \%$ & $3.2 \%$ \\
\hline \multicolumn{9}{|l|}{ Consolidated general government } \\
\hline Tax revenue & $13.1 \%$ & $11.2 \%$ & $12.4 \%$ & $37.2 \%$ & $46.2 \%$ & $12.5 \%$ & $16.5 \%$ & $15.2 \%$ \\
\hline Expenditure and net lending & $5.7 \%$ & $7.5 \%$ & $20.8 \%$ & $27.7 \%$ & $25.3 \%$ & $21.3 \%$ & $20.9 \%$ & $11.3 \%$ \\
\hline Current expenditure & $1.0 \%$ & $7.5 \%$ & $19.8 \%$ & $22.0 \%$ & $23.9 \%$ & $16.9 \%$ & $23.0 \%$ & $12.1 \%$ \\
\hline \multicolumn{9}{|l|}{ Foreign sector } \\
\hline Exports & $12.0 \%$ & $23.7 \%$ & $30.4 \%$ & $35.2 \%$ & $43.6 \%$ & $22.0 \%$ & $20.9 \%$ & $21.9 \%$ \\
\hline Imports & $3.2 \%$ & $11.7 \%$ & $32.6 \%$ & $34.8 \%$ & $37.7 \%$ & $26.1 \%$ & $16.3 \%$ & $14.7 \%$ \\
\hline \multicolumn{9}{|l|}{ Money and credits (end of period) } \\
\hline Reserve money & $9.9 \%$ & $18.4 \%$ & $13.9 \%$ & $23.9 \%$ & $29.6 \%$ & $15.3 \%$ & $11.2 \%$ & $11.7 \%$ \\
\hline Broad money M3 & $18.5 \%$ & $17.9 \%$ & $22.8 \%$ & $34.3 \%$ & $37.2 \%$ & $21.0 \%$ & $15.2 \%$ & $15.8 \%$ \\
\hline Velocity of money M3, level & 9.08 & 8.63 & 8.08 & 6.85 & 6.71 & 6.14 & 5.89 & 5.57 \\
\hline Money multiplier M3, level & 1.70 & 1.70 & 1.83 & 1.98 & 1.94 & 2.03 & 2.10 & 2.18 \\
\hline \multicolumn{9}{|l|}{ Gross international reserves } \\
\hline in months of imports of goods and services & 1.5 & 1.7 & 1.3 & 1.9 & 1.8 & 1.8 & 1.9 & 2.0 \\
\hline in million of US dollar & 159.9 & 198.4 & 201.1 & 399.4 & 372.8 & 477.7 & 582.6 & 698.5 \\
\hline \multicolumn{9}{|l|}{ Exchange rate GEL/USD } \\
\hline Period average & 2.07 & 2.19 & 2.15 & 2.00 & 1.92 & & & \\
\hline End of period & 2.06 & 2.09 & 2.08 & 1.80 & 1.80 & & & \\
\hline \multicolumn{9}{|l|}{ Interest rates, \% } \\
\hline On loans & $23.6 \%$ & $24.4 \%$ & $24.4 \%$ & $20.6 \%$ & $21.0 \%$ & & & \\
\hline On deposits & $9.6 \%$ & $10.7 \%$ & $9.6 \%$ & $8.6 \%$ & $9.0 \%$ & & & \\
\hline \multicolumn{9}{|l|}{ (In percent of GDP, unless otherwise indicated) } \\
\hline \multicolumn{9}{|l|}{ Consolidated general government } \\
\hline Total revenue and grants & $16.3 \%$ & $15.6 \%$ & $15.7 \%$ & $20.4 \%$ & $21.5 \%$ & $21.1 \%$ & $22.1 \%$ & $23.1 \%$ \\
\hline Tax revenue & $14.5 \%$ & $14.4 \%$ & $14.1 \%$ & $17.0 \%$ & $18.1 \%$ & $18.4 \%$ & $19.4 \%$ & $20.4 \%$ \\
\hline Total expenditure and net lending & $18.1 \%$ & $17.4 \%$ & $18.3 \%$ & $20.5 \%$ & $20.1 \%$ & $22.0 \%$ & $24.1 \%$ & $24.5 \%$ \\
\hline Current expenditure & $16.5 \%$ & $15.8 \%$ & $16.5 \%$ & $17.7 \%$ & $17.9 \%$ & $18.9 \%$ & $21.1 \%$ & $21.6 \%$ \\
\hline Fiscal balance, commitment basis & $-1.8 \%$ & $-1.8 \%$ & $-2.5 \%$ & $-0.1 \%$ & $1.4 \%$ & $-0.9 \%$ & $-2.0 \%$ & $-1.4 \%$ \\
\hline Fiscal balance, cash basis & $-1.6 \%$ & $-2.2 \%$ & $-1.5 \%$ & $-2.1 \%$ & $-1.5 \%$ & $-2.2 \%$ & $-2.0 \%$ & $-1.4 \%$ \\
\hline \multicolumn{9}{|l|}{ Foreign sector } \\
\hline Trade balance & $-14.5 \%$ & $-12.5 \%$ & $-14.6 \%$ & $-16.0 \%$ & $-14.3 \%$ & $-17.0 \%$ & $-16.3 \%$ & $-14.3 \%$ \\
\hline \multicolumn{9}{|l|}{ Current account balance } \\
\hline Excluding transfers & $-13.5 \%$ & $-11.9 \%$ & $-13.9 \%$ & $-15.2 \%$ & $-13.4 \%$ & $-16.2 \%$ & $-15.8 \%$ & $-14.2 \%$ \\
\hline Including transfers & $-6.3 \%$ & $-6.6 \%$ & $-10.0 \%$ & $-10.6 \%$ & $-8.8 \%$ & $-11.5 \%$ & $-11.2 \%$ & $-9.6 \%$ \\
\hline \multicolumn{9}{|l|}{ Government debts } \\
\hline Foreign debt, in percent of GDP & $52.6 \%$ & $51.0 \%$ & $43.9 \%$ & $37.1 \%$ & $35.0 \%$ & $31.3 \%$ & $29.7 \%$ & $28.1 \%$ \\
\hline Foreign debt, in percent of export & $214.2 \%$ & $177.9 \%$ & $138.1 \%$ & $105.4 \%$ & $97.5 \%$ & $82.1 \%$ & $71.3 \%$ & $60.4 \%$ \\
\hline Foreign debt service, in percent of export & $5.2 \%$ & $6.5 \%$ & $5.2 \%$ & $5.8 \%$ & $5.7 \%$ & $5.3 \%$ & $2.8 \%$ & $3.9 \%$ \\
\hline Foreign debt, in percent of budget revenue and grants & $322.7 \%$ & $326.9 \%$ & $279.1 \%$ & $182.3 \%$ & $162.8 \%$ & $148.5 \%$ & $134.7 \%$ & $121.5 \%$ \\
\hline $\begin{array}{l}\text { Government debt, in percent of budget revenue and grants } \\
\text { Foreign debt service, in percent of budget revenue and }\end{array}$ & $418.2 \%$ & $420.4 \%$ & $363.4 \%$ & $240.2 \%$ & $217.6 \%$ & $201.0 \%$ & $181.4 \%$ & $163.2 \%$ \\
\hline grants & $7.8 \%$ & $12.0 \%$ & $10.6 \%$ & $10.0 \%$ & $9.5 \%$ & $9.5 \%$ & $5.2 \%$ & $7.8 \%$ \\
\hline
\end{tabular}

Note: the calculations are made by macroeconomic model and for the reasons of consistency the data is corrected 
Policy Matrix of the EDPRP for 2005-2007

\begin{tabular}{|c|c|c|}
\hline Reforms/Measures & Implementation Date & Responsible Agency \\
\hline \multicolumn{3}{|l|}{ Improvement of Governance and Fight Against Corruption } \\
\hline $\begin{array}{l}\text { 1. To establish a single compensation policy and regulate the compensation system in the } \\
\text { public sector. }\end{array}$ & $2005-2006$ & Government, Civil Service Bureau \\
\hline 2. To elaborate a draft of a multi-year administrative/civil service reform program. & $2005-2006$ & Government, Civil Service Bureau \\
\hline $\begin{array}{l}\text { 3. To develop a concept and implementation modalities for a Personnel Control and } \\
\text { Information System. }\end{array}$ & $2005-2006$ & Civil Service Bureau \\
\hline 4. To elaborate a code of ethics for civil servants. & 2006 & Civil Service Bureau \\
\hline 5. To elaborate a national anti-corruption strategy and relevant action plan. & 2005 & Government, Security Council \\
\hline \multicolumn{3}{|l|}{ Macroeconomic Policy } \\
\hline \multicolumn{3}{|l|}{ 1. In order to improve the transparency and effectiveness of public financial management: } \\
\hline a) To prepare inventory of Legal Entities of Public Law (LEPLs) & 2005 & Ministry of Finance \\
\hline $\begin{array}{l}\text { b) To establish accounting and reporting requirements for LEPLs and Public Enterprises } \\
\text { in compliance with international accounting and reporting standards. }\end{array}$ & 2006 & Ministry of Finance \\
\hline $\begin{array}{l}\text { c) To rationalize a list of confidential procurement items and to draft an act regulating } \\
\text { confidential procurement. }\end{array}$ & 2006 & $\begin{array}{l}\text { Ministry of Justice, State Procurement Agency, } \\
\text { Ministry of Finance }\end{array}$ \\
\hline \multicolumn{3}{|l|}{ 2. In order to strengthen public budgeting and expenditure management: } \\
\hline $\begin{array}{l}\text { a) To elaborate the medium-term expenditure framework (MTEF) for 2006-2008 to be } \\
\text { envisaged in } 2006 \text { State budget. }\end{array}$ & 2005 & Ministry of Finance and other Ministries \\
\hline
\end{tabular}




\section{Reforms/Measures}

b) To Develop performance reporting/monitoring system.

\section{Pulling private capital and improving the business climate}

1. To finalize the main phase of aggressive and transparent privatization process.

2. Institutional deregulation of economy:

a) To develop standardized permitting procedures and decentralization licensing system in order to simplify licensing and permit issuance procedures.

b) To Create Independent Multisectoral Tariff Regulating Board.

3. To prepare and disseminate standardized requirements for company registration procedures and to abolish unnecessary notarization requirements.

4. To develop and implement country branding strategy.

5. To finalize preparation of the new customs code.

6. To develop an appropriate legislative basis for accreditation and conformity assessment.

7. To draft and implement technical safety regulation, associated with the European New Approach

\section{To establish an independent National Accreditation Body.}

9. To establish technical committees for the elaboration of standards according to the WTO code for standardization.

10. Streamline the court administration and case modern management system.

11. To create a single public register which will cover: civil, public, legal entities (other than business), political unions, controlling bodies, licensing and permits and normative
Implementation Date

2007

Responsible Agency

Ministry of Finance

2005-2007

2005-2006

2005-2006

2005

$2005-2006$

2006

2005-2007

$2005-2007$

2007

2005-2007

\begin{tabular}{l} 
Ministry of Economic Development \\
Government \\
Government \\
Government \\
Government \\
Ministry of Finance \\
Government \\
Ministry of Justice \\
Ministry of Economic Development \\
Ministry of Economic Development \\
\hline Ministry of Economic Development \\
\hline
\end{tabular}




\begin{tabular}{|c|c|c|}
\hline Reforms/Measures & Implementation Date & Responsible Agency \\
\hline \multicolumn{3}{|l|}{ act registers. } \\
\hline \multicolumn{3}{|l|}{ Improvement of Risk Management in the Health and Social Protection Sphere } \\
\hline \multicolumn{3}{|l|}{ 1. To reduce extreme poverty by implementing targeted social assistance program. } \\
\hline a) To introduce benefit targeted program (monetization). & $2005-2006$ & $\begin{array}{l}\text { Ministry of Finance, Ministry of Labor, Health and } \\
\text { Social Affairs }\end{array}$ \\
\hline b) To prepare a package of non-cash benefit targeted program. & 2007 & Ministry of Labor, Health and Social Affairs \\
\hline 2. Pension arrears continue to be cleared. & 2005 & $\begin{array}{l}\text { Ministry of Finance, Ministry of Labor, Health and } \\
\text { Social Affairs }\end{array}$ \\
\hline \multicolumn{3}{|l|}{ 3. Pension reform: } \\
\hline a) To elaborate reform concept and conduct its public discussion. & 2005 & Ministry of Labor, Health and Social Affairs \\
\hline b) To Elaborate strategy on protection against poverty in the old age. & 2006 & Ministry of Labor, Health and Social Affairs \\
\hline $\begin{array}{l}\text { 4. To implement measures towards social integration of the handicapped and recording } \\
\text { and systemizing their individual data. }\end{array}$ & $2005-2007$ & Ministry of Labor, Health and Social Affairs \\
\hline 5. To implement the program supporting the social adaptation of the disabled. & $2005-2007$ & Ministry of Labor, Health and Social Affairs \\
\hline $\begin{array}{l}\text { 6. To elaborate and adopt a new Labor Code in order to improve functioning of the labor } \\
\text { market. }\end{array}$ & $2005-2006$ & Ministry of Labor, Health and Social Affairs \\
\hline $\begin{array}{l}\text { 7. To ensure compliancy with international standards in health sector and to introduce } \\
\text { insurance principles. }\end{array}$ & $2005-2007$ & Ministry of Labor, Health and Social Affairs \\
\hline $\begin{array}{l}\text { 8. To determine clearly the basic package of medical care in order to ensure the } \\
\text { accessibility of medical care within the scope of availability. }\end{array}$ & 2005 & Ministry of Labor, Health and Social Affairs \\
\hline 9. To reconsider and revise the basic package of medical care for mothers and children. & 2005 & Ministry of Labor, Health and Social Affairs \\
\hline
\end{tabular}




\section{Reforms/Measures}

10. To improve the material-technical base of medical institutions providing care for mothers and children.

11. To conduct consideration of each case involving the death of the mother and a selective consideration of cases of a child's death in order to elaborate relevant preventive measures.

12. To supervise the healthcare of a child, identifying individuals and groups with development and growth disorders.

\begin{tabular}{|l|l|}
\hline $2005-2007$ & Ministry of Education and Science \\
\hline $2005-2007$ & Ministry of Education and Science \\
\hline $2005-2006$ & Ministry of Education and Science \\
\hline $2005-2006$ & Ministry of Education and Science \\
\hline $2006-2007$ & Ministry of Education and Science \\
\hline $2006-2007$ & Ministry of Education and Science \\
\end{tabular}

Implementation Date

2005-2007

2005

2005

Responsible Agency

Ministry of Labor, Health and Social Affairs

Ministry of Labor, Health and Social Affairs

Ministry of Labor, Health and Social Affairs

(2005

\section{Education}

1. To conduct institutional and program reform of general education

2. To ensure compliance with international standards in the education system.

3. To develop a concept - "Education for sustainable development".

4. To elaborate a new concept, which envisages the creation of a comprehensive system of vocational education, the optimization of the network of professional education institutions and their substance-based and structural adjustment.

\section{To develop targeting mechanisms in order to support poor students as part of an} education finance strategy.

6. To draft standards and curriculum programs for assessment in the medium term.

7. To increase financing of science following the introduction of a new management and financing mechanism. 


\section{Energy}

1. To elaborate a new management model of energy sector.

2. To eradicate energy deficit.

3. To introduce international accounting standards in electricity sector in order to assure transparency.

4. To improve cash collection rates on consumed electricity and natural gas.

5. To rehabilitate the transmission line and ensuring activity of EngurHES and to protect its stability.

\section{Transport and Communications}

1. To organize direct ferry navigation to Black sea and Mediterranean sea ports through Georgian ports.

2. To implement the first phase of Karsi-Axalqalaqi-Tbilisi-Baku trunk-railway project.

3. To liberalize the civil aviation.

4. To improve Tbilisi and Batumi airports' infrastructure in compliance with world standards.

5. To improve navigation systems in order to meet international civil aviation requirements.

6. To elaborate a concept on e-governance.

7. To integrate informational-telecommunication systems of Georgia into the regional informational-telecommunication corridor.

8. To ensure rehabilitation of interregional roads and to start building of new mainlines.

\begin{tabular}{|l|}
\hline $2005-2007$ \\
\hline $2005-2006$ \\
\hline $2005-2006$ \\
\hline $2005-2007$
\end{tabular}

Government

Ministry of Energy, Ministry of Finance

Ministry of Energy

Ministry of Energy

Ministry of Energy

\begin{tabular}{|l|l|}
\hline $2005-2007$ \\
\hline $2005-2006$ \\
\hline $2005-2007$ \\
\hline $2005-2007$ \\
\hline $2006-2007$ \\
\hline $2005-2007$ \\
\hline $2005-2007$
\end{tabular}

Ministry of Economic Development

Ministry of Economic Development

Ministry of Economic Development

Ministry of Economic Development

Ministry of Economic Development

Government

Ministry of Economic Development

Ministry of Economic Development 


\section{Tourism}

1. To actively participate and promote Georgian tourist products at international tourist fares and exhibitions.

\section{Agriculture Sector Development}

1. To adopt a law on food safety and ensure implementation of administrative-institutional reform in the sector.

2. To establish a private veterinary service and a network of laboratories through the reform of the Veterinary Department.

3. To establish a service with a single and strong regulatory function on the basic of the Vegetation Protection Service, inspections on testing selective achievements and the quality of seeds and seeding materials, in condition of transferring economic responsibilities into private management.

4. To support agriculture development in mountain and highly mountainous regions.

5. To support establishment of credit unions' development in rural areas.

6. To implement the project "Poverty Reduction in Kvemo Kartli and Samtskhe Javakheti" in order to assist social and economic development in rural areas.
Ministry of Economic Development

\begin{tabular}{l}
$2005-2007$ \\
\hline $2005-2006$ \\
\hline $2005-2007$ \\
\hline $2005-2007$ \\
\hline $2005-2007$ \\
\hline $2005-2007$
\end{tabular}

Ministry of Agriculture

Ministry of Agriculture

Ministry of Agriculture

Ministry of Agriculture

Ministry of Agriculture

Ministry of Agriculture

\section{Environment Protection}

1. To implement the project on developing national reserves in the forestry eco-systems of the Central Caucasus.

2. To Introduce "Clean Development Mechanism"
2005

$2005-2007$ Resources

Ministry of Environment Protection and Natural Resources 


3. To implement project aiming at assisting the private sector players engaged in
renewable energy projects. To elaborate the sector development strategy in cooperation
with the Ministry of Energy.
$\begin{aligned} & \text { 4. To ensure maximal coverage of possible negative outcomes of the foreseeable changes } \\ & \text { in climate conditions by various sectoral strategies and programs. }\end{aligned}$

2005-2007

in climate conditions by various sectoral strategies and programs.
Ministry of Environment Protection and Natural Resources, Ministry of Energy

2005-2007

Ministry of Environment Protection and Natural

Resources

\section{Improvement of Socio-Economic Conditions of the Post-Conflict Zones}

1. To implement the third phase of Tskivali rehabilitation program focused on energy, water supply and social spheres financed by the European commission.

2. To implement rehabilitation project of the Georgian-Abkhaz conflict zone (utilization of waste and water pipes, rehabilitation of 4 hospitals in Abkhazia, fortifying

embankments of river Kodori to prevent floods) financed by the European Commission.

3. To implement social rehabilitation programs in Gali region and adjacent territories (namely Ochamchire and Tkvarcheli) financed by the European Commission and UNDP.

4. To implement the concluding phase of the New Approach Program towards temporary integration of IDPs in social-economic activities.

\begin{tabular}{|l|l|}
\hline $2005-2006$ & Government \\
\hline $2005-2007$ & Government \\
\hline $2005-2007$ & Government \\
\hline 2005 & Government \\
\hline
\end{tabular}

\section{EDPRP Coordination}

1. To prepare and publish comprehensive poverty profile.

Regularly

Ministry of Economic Development

2. To prepare of EDPRP Annual Progress Report.

Ministry of Economic Development 